\title{
POKRŠTENI TURCI U ZADRU U 17. STOLJEĆU PREMA MATICAMA KRŠTENIH KATEDRALNE ŽUPE SV. STOŠIJE
}

\author{
Zdenko DUNDOVIĆ \\ Zadar, Hrvatska
}

\author{
UDK: 265.1:929.53(497.5 Zadar)“16“ \\ DOI: http://doi.org/10.21857/moxpjhg4vm \\ Izvorni znanstveni rad \\ Prihvaćeno: 22. veljače 2017.
}

U hrvatskoj historiografiji pitanje pokrštavanja Turaka tijekom 17. stoljeća u dalmatinskim gradovima malo je istraženo. Štoviše, s obzirom na kompleksnost tog pitanja, nedovoljno istraženu građu u državnim i crkvenim arhivima i činjenicu da se pokrštavanje Turaka u razmatranom razdoblju često veže uz trgovinu roblja, tema je izazovna i iziskuje temeljit pristup sine ira et studio. Cilj je ovog rada na temelju popisa iz matičnih knjiga župe sv. Stošije u Zadru o krštenim Turcima i osobama s osmanskog teritorija tijekom 17. stoljeća pokušati rasvijetliti uzroke i posljedice tih krštenja te ih analizom dostupnih podataka dovesti u korelaciju s trgovinom robljem u Dalmaciji u razmatranom razdoblju.

Ključne riječi: pokrštavanje Turaka, krštenje, Zadar, 17. stoljeće, trgovina robljem.

\section{UVOD}

U hrvatskoj historiografiji o trgovini robljem u 17. stoljeću pisala je Tea Perinčić Mayhew. ${ }^{1}$ O pokrštavanju Turaka u 17. stoljeću pisao je Danilo Klen. ${ }^{2}$ Drago Roksandić navodi da su spoznaje o mletačkom ropstvu u ranom novom vijeku nedovoljno istražene, iako za to ima više izvornih potvrda. ${ }^{3}$ Zanimljiv je rad Krste Stošića koji će poslužiti za komparaciju problematike između zadarskog i

1 Tea Perinčić Mayhew, Prodaja roblja na Jadranu u 17. stoljeću, Miscellanea Hadriatica et Mediterranea, br. 1, Zadar, 2013., 107 - 118. Neke spomene o toj tematici donose: Ivan GRGIĆ, Prva agrarna reforma na mletačkoj „novoj stečevini“ u Dalmaciji, Izdanje Muzeja grada Splita, Split, 1962., 13; Roman Jelić, Pad Novigrada u turske ruke i bijeg Novigrađana u Pag, Zadarska revija, god. XXXVIII, br. 5-6, Zadar, 1989., 544; Grozdana FrANov-ŽIv ković, Matične knjige i evidencije Ninske i Zadarske nadbiskupije: izvor za proučavanje stanovništva župe Novigrad od 17. do sredine 19. stoljeća, Novigrad nekad i sad (ur. Slobodan KAšTELA i dr.), Zadar, 2016., 418; G. Franov-ŽIvković, Svakidašnji život na mletačko-turkoj granici na području Zemunika u 17. st. na temelju dokumenata pisanih hrvatskom ćirilicom (bosančicom) i glagoljicom, Zemunik u prostoru i vremenu (ur. Josip FARIčić, Zdenko Dundović), Zadar, 2016., 174 - 178; Ivan Pederin, Odnosi između Raba i Paga u XVI. st., Pag u prošlosti i sadašnjosti (ur. Šime Batović), Pag, 2017., 205.

2 Danilo KLen, Pokrštavanje „turske“ djece u Rijeci u XVI i XVII stoljeću, Historijski zbornik, Šidakov zbornik, (ur. Mirjana Gross), godina 29-30, Zagreb, 1977., 203 - 207.

3 Drago Roksandić, Triplex Confinium, Zagreb, 2003., 129. 
šibenskog kraja. ${ }^{4}$ Buduću ova tematika u hrvatskoj historiografiji nije dovoljno obrađena to nam govori o potrebi daljnjeg istraživanja s obzirom na nedostatak informacija o trgovini robljem u razdoblju ranog novog vijeka te na bogatu građu u dalmatinskim arhivima o muslimanima koje su kršćani zarobljavali i prodavali na trgovištima dalmatinskih komuna. ${ }^{5}$ Jedno od tih trgovišta bilo je u Zadru.

Zadar, a osobito njegovo zaleđe, tijekom 17. stoljeća bilo je na poseban način turbulentno područje u vojnom, demografskom, sociološkom i religioznom smislu. $U$ vojnom smislu turbulencije u zadarskom zaleđu započinju sredinom 17. stoljeća za vrijeme Kandijskog rata (1645. - 1669.). Naime, istočno jadransko bojište u jeku mletačko-osmanskih sukoba spadalo je u periferna područja ratovanja, $s$ obzirom na to da se glavnina sukoba vodila oko prevlasti nad mletačkim posjedima $u$ istočnom Sredozemlju. ${ }^{6}$ Područje zadarskog zaleđa u to je vrijeme geostrateški prostor razgraničenja Mletačke Republike, Osmanskoga Carstva i Habsburške Monarhije. Taj će prostor Osmanlije postupno zauzimati nakon pada Bosne 1463. godine što će za posljedicu imati velike migracije hrvatskog stanovništva i postupno opadanje stanovnika u zadarskom zaleđu s mletačke is otomanske strane granice nakon Ciparskog rata (1570. - 1573.) i konačnog razgraničenja 1576. godine. Time je ovo područje pretvoreno u nemirnu granicu na kojoj su česti neprijateljski upadi, pljačka i otimačina postali dio svakodnevlja tijekom službenog mira koji je potrajao nekih osamdesetak godina. ${ }^{7}$ Prekretnica nastaje početkom Kandijskog rata 1645. godine, kada Mlečani na ovom prostoru napuštaju defenzivno ratovanje i prelaze u ofenzivu te, zahvaljujući prvenstveno prebjezima s osmanskog teritorija - Morlacima - i njihovu specifičnom, gerilskom načinu ratovanja, uspijevaju tijekom Morejskog rata potisnuti Turke dublje prema Bosni i proširiti svoj teritorij u dalmatinskom zaleđu. Mlečani su odmah prepoznali veliku korist u morlačkim odredima te Venecija započinje regrutiranje velikih skupina Morlaka i iz unutrašnjosti osmanskog područja. ${ }^{8}$ Dolazak Morlaka na ove prostore tijekom i između Kandijskog i Morejskog rata postat će, između ostalog, i prijeporno pitanje crkvene jurisdikcije katoličkih biskupa nad novopridošlim stanovništvom koje je pripadalo različitim obredima

4 Krsto STošıć, Turski robovi iz XVII. vijeka u Šibeniku, Bogoslovska smotra, god. XXIV, Zagreb, 1936., $87-101$.

5 T. Perinčić Mayhew, Prodaja roblja na Jadranu, 116.

6 Tea Perinčić Mayhew, Zadarsko zaleđe između osmanske i mletačke uprave 1645.-1718., Dalmacija u prostoru i vremenu. Što Dalmacija jest, a što nije? (ur. Lena Mirošević, Vera Graovac MatASsi), Zadar, 2014., 52.

T. Perinčić Mayhew, Zadarsko zaleđe, 53.

8 Mile Bogović, Katolička Crkva i pravoslavlje u Dalmaciji za mletačke vladavine, Zagreb, 1993., 7. 
(latinskom i grčkom) te je tijekom 17. i 18. stoljeća novonastala situacija rezultirala mnogim kontroverzama u religioznom smislu. ${ }^{9}$

Zahuktavanjem ratnih sukoba u drugoj polovici 17. stoljeća pojačao se i intenzitet trgovine robljem. Tu su praksu, kako naglašava Tea Perinčić Mayhew, poticali sami mletački službenici u Dalmaciji, a glavni nositelji te trgovine bili su domaći ljudi u dalmatinskim komunama te vojnici plaćenici koji su služili na dalmatinskom ratištu. ${ }^{10}$

Istraživanje za potrebe ovog rada izvršeno je na temelju upisa pokrštenih Turaka u maticama krštenih katedralne župe Sv. Stošije u Zadru tijekom 17. stoljeća. Matične knjige župe sv. Stošije čuvaju se u arhivu Zadarske nadbiskupije $\mathrm{u}$ fondu Zbirke matičnih knjiga i parica matičnih knjiga Zadarske nadbiskupije, pod signaturom HR-AZDN-43. Ovdje su uzete u obzir matične knjige krštenih za razdoblje od 1600. do 1700. godine, sveukupno deset matičnih knjiga, označenih nazivom Liber Baptizatorum i rimskim brojevima V - XIV. Radi pojednostavljenja citiranja, u bilješkama se rabi Liber i brojčana oznaka matične knjige krštenih. U sljedećoj tablici navodi se razdoblje koje obuhvaća svaka pojedina matična knjiga krštenih.

TABLICA 1. Razdoblja obubvaćanja pojedinih matičnih knjiga krštenih župe sv. Stošije u 17. stoljeću

\begin{tabular}{|l|l|l|l|l|}
\hline Liber $V$ & Liber VI & Liber VII & Liber VIII & Liber IX \\
\hline $1595 .-1604$. & $1604 .-1608$. & $1608 .-1615$. & $1615 .-1629$. & $1629 .-1643$. \\
\hline Liber $X$ & Liber XI & Liber XII & Liber XIII & Liber XIV \\
\hline $1643 .-1656$. & $1656 .-1674$. & $1674 .-1685$. & $1685 .-1696$. & $1696 .-1707$. \\
\hline
\end{tabular}

\section{TRGOVINA ROBLJEM U 17. STOLJEĆU U DALMATINSKIM KOMUNAMA}

$\mathrm{Na}$ istočnoj obali Jadrana u srednjem vijeku trgovina robljem odvijala se utabanim pravcima iz Bosne prema dalmatinskim gradovima. Značajna ruta trgovine robljem išla je dolinom rijeke Neretve do njezina ušća. Važno trgovačko središte za prodaju roblja bio je Dubrovnik iz kojega se roblje iz slavenske unutrašnjosti transferiralo prema Apeninskom poluotoku. ${ }^{11}$ No i

9 M. Bogović, Katolička Crkva i pravoslavlje, 8.

10 T. Perinčić MAYHEW, Prodaja roblja na Jadranu, 110.

11 O tome više kod: Paola Pinelli, Od Dubrovnika do Firenze: bilješke o novačenju posluge u 15. stoljeću, Anali Zavoda za povijesne znanosti HAZU u Dubrovniku, br. 46, Dubrovnik, 2008. $65-80$. 
ostali dalmatinski gradovi sudjelovali su, u manjoj ili većoj mjeri, u trgovini robljem. Trgovina robljem pravno je regulirana statutima dalmatinskih komuna, ${ }^{12}$ a robovi su u dalmatinskim gradovima držani u statusu servi et ancille i uglavnom su koristili kao radna snaga. ${ }^{13}$ Gospodar je mogao roba osloboditi, ako je htio. Ta je praksa često sadržana u oporukama gospodara kao čin pobožnosti koji je Crkva poticala. ${ }^{14}$ Kako navodi T. Mayhew, Katolička crkva odobravala je zarobljavanje bosanskih katara pod uvjetom da se pokrste. Na taj je način pokrštavanje bilo vrlo dobar izgovor za porobljavanje u Bosni i prodaju robova u dalmatinskim trgovištima. ${ }^{15}$

Situacija se mijenja tijekom 15. stoljeća kada Osmanlije provaljuju u Bosnu. Odvođenje robova, ovaj put prema istoku, na tržišta Osmanskog Carstva, postaje taktikom osvajanja neprijateljskog teritorija. Kršćanska je obrana na istočnoj obali Jadrana u to vrijeme uključivala posebne postrojbe uskoka koji su bili jedini odgovor na česte turske upade s obzirom na gerilsku vojnu taktiku. Zajedno s obranom, uskoci obnavljaju i trgovinu robljem, ali ne kao njezini nositelji, već isključivo radi zarade, odnosno otkupa (riscatto) osmanskih podanika u dalmatinskim gradovima. Uz to, uskoci su često prodavali roblje mletačkim galijama koje su potrebovale ljudske snage (veslači). Važno je primijetiti da su uskoci držali kako i osmanski kršćani mogu biti zarobljeni i prodani u roblje. ${ }^{16}$ Uz to, uskoci su dijelom opskrbljivali robljem i talijansko tržište, ali i rimskog papu $^{17}$ čija je mornarica, kao i toskanska, bila opremljena robovima s istočnog Jadrana. ${ }^{18}$ Postoje zapisi koji svjedoče o osobnoj umiješanosti nekih papa tijekom 15. do 18. stoljeća u kupovinu robova za papinsku mornaricu. Takvi se robovi mogu podijeliti u tri skupine: u prvu skupinu spadaju zločinci osuđeni na doživotnu robiju, u drugu skupinu nekršćanski zarobljenici rata koji su mogli biti razmijenjeni i u treću skupinu tzv. dobrovoljci (bonavoglie) koji su se zbog siromaštva sami prodali u ropstvo i nakon završetka ugovornog razdoblja mogli biti oslobođeni, pod uvjetom dobrog ponašanja. ${ }^{19}$

12 T. Perinčić Mayhew, Prodaja roblja na Jadranu, 109; Neven BudAK, Trgovina radnom snagom na istočnom Jadranu - razvoj i značaj, Historijski zbornik, 37 (1), Zagreb, 1984., 129 - 132.

13 O tome više kod: N. BudAK, Trgovina radnom snagom na istočnom Jadranu, $105-138$.

14 T. PERINČić MAYHeW, Prodaja roblja na Jadranu, 108 - 109.

15 T. Perinčić MaYhew, Prodaja roblja na Jadranu, 109.

16 T. Perinčić MaYhew, Prodaja roblja na Jadranu, 110.

17 Usp. Salvatore Bono, Schiavi in Italia: Maghrebini, neri, Slavi, Ebrei e altri (secc. XVI-XIX), dostupno online, URL: http://www.storiamediterranea.it/public/md1_dir/r1528.pdf (zadnje posjećeno 4. lipnja 2017.), 243.

18 T. Perinčić MaYhew, Prodaja roblja na Jadranu, 109 - 110.

19 John Francis Maxwell, Slavery and the Catholic Church: The History of Catholic Teaching concerning the Moral Legitimacy of the Institutions of Slavery, London, 1975., 76. 
$S$ druge strane, na osmanskom teritoriju glavni akteri u trgovini robljem bili su Morlaci organizirani u neregularne vojne postrojbe zvane martolosi. Morlaci su bili najvećim dijelom slavenskog kršćanskog podrijetla i kao takvi glavni sudionici mletačko-osmanskih sukoba na istočnoj strani Jadrana u 17. stoljeću pa su usporedo $s$ trgovcima postali i glavna roba u trgovini robljem $u$ razmatranom razdoblju. ${ }^{20}$ Treba naglasiti da ni državni, a ni crkveni zakoni nisu dopuštali zarobljavanje kršćana. Tako mletački podanici više nisu bili glavne žrtve osmanske trgovine robljem, štoviše oni su preuzeli tu istu trgovinu koja je postala unosan posao u kojemu je i sama Mletačka Republika vidjela interes. O tome jasno svjedoči činjenica da je mletački Senat nastojao trgovinu robljem držati pod kontrolom. Zbog toga je uvedena desetina (decima) za svakog prodanog roba o čemu su brigu u dalmatinskim komunama vodili kneževi i kancelari. ${ }^{21} \mathrm{Za}$ Mletačku Republiku pitanje trgovine robljem bilo je pitanje granične ekonomije ekvivalentno krijumčarenju ili pljački koje je trebalo dovesti u red. ${ }^{22}$ T. Mayhew navodi da je postojala pravna odredba da se svi robovi koji dolaze na mletački (kršćanski) teritorij prije nego budu dalje prodani trgovcima, koji su u Zadar dolazili is Apeninskog poluotoka radi trgovine robljem, budu kršsteni. ${ }^{23}$

\section{ANALIZA UPISA POKRŠTENIH TURAKA U MATICAMA KRŠTENIH ŽUPE SV. STOŠIJE U ZADRU TIJEKOM 17. STOLJEĆA.}

$\mathrm{Na}$ temelju analize matičnih knjiga krštenih vođenih pri katedralnoj župi sv. Stošije u Zadru moguće je utvrditi više relevantnih činjenica o krštenju Turaka tijekom 17. stoljeća. Obrazac upisivanja krštenja Turaka u tim matičnim knjigama u prvoj polovici 17. stoljeća prati specifičnost izraza già Turco odnosno già Turca, dok se u drugoj polovici istog stoljeća koristi jednostavno Turco. Izraz Turco u ono je vrijeme općenito označavao nekoga tko dolazi iz daleka, ${ }^{24}$ kako navodi Samuela Marconcini. ${ }^{25}$ Stoga se uz izraz Turco redovito kod upisa navodi

20 T. Perinčić MAYhew, Prodaja roblja na Jadranu, 111.

21 Usp. K. STošıć, Turski robovi iz XVII. vijeka u Šibeniku, 88.

22 Tea Maynew, Dalmatia between Ottoman and Venetian Rule. Contado di Zara 1645-1718, Rim, 2008., 266.

23 T. MAYHew, Dalmatia between Ottoman and Venetian Rule, 265.

24 U radu se koristi izraz Turci ili Turčin koji označava osobu ili osobe krštene tijekom 17. stoljeća u Zadru, a dovedene su s tadašnjih teritorija pod osmanlijskom upravom.

25 Samuela Marconcini, Una presenza nascosta: battesimi di 'turchi' a Firenze in età moderna, Anali di Storia di Firenze, 7 (2012), 98, dostupno online, URL: https://www.academia.edu/3151310/ Una_presenza_nascosta_battesimi_di_turchia_Firenze_in_età_moderna (zadnje posjećeno 4 . lipnja 2016.) 
i religiozna pripadnost islamu izrazom maometismo ili mahometismo. Rjeđe se $\mathrm{u}$ zapisima rabi izraz Turchescho, $-a,-i$, i to isključivo pri krštenju Turaka za koje se smatralo da su možda već kršteni (kršćani konvertirani na islam).

Uz to, osobito tijekom druge polovice 17. stoljeća, u matičnim upisima redovito se navodi i status (službe) pokrštenih Turaka u kućama njihovih gospodara, imena njihovih gospodara, a nerijetko i društveni status gospodara kojemu pripadaju. Tako se u maticama krštenih pokršteni Turci negdje upisuju kao servus i serva, negdje schiavo i schiava, negdje essistente, negdje habitante, ${ }^{26}$ a negdje i servitore i schiavetta. Razlika u upisu statusa pokrštenih Turaka u kućama njihovih gospodara pritom nije bila sinonim za bolji tretman odnosno kvalitetnije životne uvjete turskih robova u pojedinim zadarskim obiteljima u 17. stoljeću. Paola Pinelli na temelju svojih istraživanja smatra da služinčad nije bila u ništa boljem položaju od roblja jer je i ona mogla biti prodana, kupljena, zaplijenjena zbog dugova gospodara, posuđena ili pak davana u miraz. ${ }^{27} \mathrm{U}$ svakom slučaju, iz upisa u matice krštenih tijekom 17. stoljeća u Zadru može se zaključiti da je najveći broj tada pokrštenih Turaka bio u službi sluga i sluškinja u kućama bolje stojećih građana.

Imena koja su pokršteni Turci dobivali na krštenju odražavaju onodobnu tradiciju kršćanske onomastike. Od 195 pokrštenih Turkinja najviše (43) ih je kršteno imenom Katarina, 27 imenom Marija, 16 imenom Magdalena, zatim Lucija, Jeronima i Domenika, dok kod muškaraca prevladava Ivan (Zvane) (35), a zatim slijede imena Ivan Krstitelj, Petar, Pavao, Jeronim, Marko i Antun. Nerijetko su pokrštenim Turcima davana imena njihovih kumova. Zamjetno je također da nadijevanje imena ovisi i o blizini liturgijskog slavlja određenog svetca ili svetice koja se slavi u tom mjesecu u kojemu je krštenik primio sakrament. U gotovo $90 \%$ slučajeva pokrštenim Turcima tijekom 17. stoljeća u Zadru kumovi su najviđeniji građani - generalni providur ili njegovi ovlaštenici, zadarski knez, zadarski kapetan, zadarski kaštelan i kamerlengo, visoki vojni časnici, ugledni plemići i građani te njihove supruge, tek rijetko obrtnici, a najrjeđe sami gospodari, i to u slučajevima krštenja zbog neposredne opasnosti i gotovo uvijek u kućama. ${ }^{28}$ Jednako tako, kako crkveni kanoni nalažu, krstitelj

26 Dana 20. siječnja 1648. godine kršten je Karlo Sebastijan, Turčin, nastanjen (habitante) kod Aleksandra Dieda, zadarskog kneza. Liber X, fol. 130r.

27 Paola Pinelli, Od Dubrovnika do Firenze: bilješke o novačenju posluge u 15. stoljeću, Anali Zavoda za povijesne znanosti HAZU, br. 46, Dubrovnik, 2008., 73.

28 Danilo Klen istaknuo je kao zanimljivost da je pri krštenju mladića, roba, u Rijeci kao prvi svjedok fungirao sam riječi kapetan Ferdinand barun Ruere. D. KLEN, Pokrštavanje „turske“ djece u Rijeci, bilj. 13, 205. To je zapravo bila uobičajena praksa u dalmatinskim komunama. Usp. K. STošić, Turski robovi iz XVII. vijeka u Šibeniku, 88 - 97. 
je često zadarski nadbiskup ili njegov ovlaštenik, redovito iz vrha crkvene hijerarhije (arhiđakoni, arhiprezbiteri, primiceri, generalni vikari, kanonici, župnici katedralne crkve...).

Sveukupno je u Zadru tijekom 17. stoljeća kršteno 397 Turaka, od toga 161 muškog spola, 195 ženskog spola i 41 osoba kojoj, zbog nedostatka upisanih podataka u maticama, ne možemo odrediti spol (Tablica 2). Usporedbe radi, u razdoblju od 1599. do 1724. godine u Firenci je kršteno 308 Turaka, i to više muškaraca (183) nego žena (125). ${ }^{29}$ Uzmemo li u obzir da Firenca u to vrijeme ima više od 75000 stanovnika, a Zadar brojem stanovnika varira tijekom 17. stoljeća od 2000 do $6000,{ }^{30}$ moguće je da upisi o trgovini robljem nisu uvijek bili vođeni marno, o čemu je već izvijestila Paola Pinelli, te je njihov broj zasigurno bio i veći. ${ }^{31}$ Svakako, ovome treba pridodati činjenicu postojanja ilegalnog tržišta robljem što dodatno otežava mogućnost preciziranja njihova broja tijekom 17. stoljeća. Jednako tako, ni broj krštenih Turaka u Zadru zasigurno ne pokazuje pravo brojno stanje $s$ obzirom na to da je npr. $u$ rujnu 1658. godine generalni providur Petar Valier napisao u izvješću da 520 muškaraca, 98 žena i 46 djece čeka da ih se proda. ${ }^{32} \mathrm{U}$ Toskani se u drugoj polovici 17 . stoljeća bilježi porast konverzije na kršćanstvo onih Turaka koji dolaze iz Dalmacije, ${ }^{33}$ a i Zadar je, ipak u manjoj mjeri od Dubrovnika, dalmatinska komuna s čijeg tržišta roblje odlazi prema Toskani, što dodatno potkrepljuje činjenicu postojanja vrlo aktivne trgovačke mreže robljem s istočne obale Jadrana prema Apeninskom poluotoku, točnije njegovu južnom dijelu. ${ }^{34}$

U razdoblju od 1600. do 1680. godine pratimo u Zadru razmjeran broj krštenja muških i ženskih Turaka i Turkinja, dok je u dva posljednja desetljeća 17. stoljeća zamjetno veći broj krštenih osoba ženskog spola. Od ukupnog broja krštenih u 17. stoljeću njih 16 umrlo je nedugo nakon krštenja. Zamjetno je povećanje broja krštenih u razdobljima u kojemu počinju Kandijski (1645.) i Morejski rat (1684.). To ne začuđuje $s$ obzirom na to da se intenzitet trgovine robljem pojačao upravo $u$ to vrijeme. ${ }^{35}$

29 S. MARConcini, Una presenza nascosta, 99.

30 Vera Graovac, Populacijski razvoj Zadra, Geoadria, br. 1., Zadar, 2004., 56.

31 P. Pinelli, Od Dubrovnika do Firenze, 72.

32 T. PERINČIĆ MAYHEW, Prodaja roblja na Jadranu, 112.

33 S. MARConcini, Una presenza nascosta, 101.

34 Usp. Domagoj Madunić, Conversion Under the Threat of Arms. Converts and Renegades during the War for Crete (1645-1669), 2 - 3, dostupno online, URL: https://www.academia.edu/3673707/ Conversion_Under_the_Threat_of_Arms._Converts_and_Renegades_during_the_War_for_ Crete_1645-1669_(zadnje posjećeno 2. lipnja 2017.); S. Bono, Schiavi in Italia, 237.

35 T. Perinčić MaYhew, Prodaja roblja na Jadranu, 111. 
TABLICA 2. Kršteni Turci prema spolu po desetljećima

\begin{tabular}{|c|c|c|c|}
\hline Razdoblje krštenja & Muških & Ženskih & Nepoznatog spola \\
\hline $1600 .-1610$. & 16 & 12 & $/$ \\
\hline $1611 .-1620$. & 9 & 4 & $/$ \\
\hline $1621 .-1630$. & 9 & 10 & $/$ \\
\hline $1631 .-1640$. & 11 & 10 & 41 \\
\hline $1641 .-1650$. & 45 & 40 & $/$ \\
\hline $1651 .-1660$. & 14 & 13 & $/$ \\
\hline $1661 .-1670$. & 2 & 4 & $/$ \\
\hline $1671 .-1680$. & 17 & 2 & $/$ \\
\hline $1681 .-1690$. & 22 & 51 & 41 \\
\hline $1691 .-1700$. & 16 & 49 & 195 \\
\hline Sveukupno & 161 & & \\
\hline
\end{tabular}

Izvor: Arhiv Zadarske nadbiskupije (dalje: HR-AZDN-43), Zbirka matičnih knjiga i parica matičnih knjiga Zadarske nadbiskupije, župa sv. Stošije - Zadar, matične knjige od 1595. do 1707.

Tea Perinčićnavodi da su svi robovi trebali biti pokršteni nakon što su dovedeni s osmanskog teritorija, a prije prodaje, kako je nalagao zakon. ${ }^{36}$ Uzmemo li u obzir toskanski slučaj, tj. činjenicu da su robovi kupljeni na mletačkom teritoriju, a kršteni na toskanskom, te zapise iz matica krštenih u Zadru tijekom 17. stoljeća, vidimo da praksa trgovine robljem nije uvijek pratila pravne odredbe. Primjerice, 31. kolovoza 1684. stoji zapisano da je don Antun Buscarolo dopuštenjem zadarskog nadbiskupa Ivana Evanđeliste Parzaghija (1669. - 1688.) krstio dijete roba kojega je kupio Rade Filipović iz Budina, pravoslavac. ${ }^{37}$ Dijete je dakle prodano, a tek onda kršteno. Nadalje, velik broj krštenja u kućama gospodara, osobito u vrijeme zaraze, o čemu će još biti riječi, navodi na zaključak da su ti robovi, sluge i služinčad već kupljeni, s obzirom na to da su već u službi u kućama svojih gospodara, a pokršteni tek kad su se našli u životnoj opasnosti. I Danilo Klen navodi da je Zadranin Šimun De Conti doveo sa sobom u Rijeku jednog roba, mladića od 14 do 15 godina, kojega je krstio riječki župnik. ${ }^{38}$

Samuela Marconcini naglasila je česta skupna krštenja desetaka Turaka kako bi se veličalo njihovo obraćenje, a na štetu njihove individualnosti. ${ }^{39} \mathrm{~S}$ druge strane, Domagoj Madunić naglasio je da se skupnim krštenjima Mletačka Republika odricala važne veslačke snage na galijama što joj nikako nije odgovaralo. ${ }^{40}$

39 S. MARCONCINI, Una presenza nascosta, 104.

40 D. Madunić, Conversion Under the Threat of Arms, 2 - 3. 
U maticama krštenih župe sv. Stošije zabilježen je samo jedan slučaj skupnog krštenja Turaka. Naime, 10. prosinca 1647. godine zadarski nadbiskup Bernard Florio (1642. - 1656.) krstio je u zadarskoj katedrali različite Turke, njih ukupno 41. Osim te informacije ništa drugo nije zapisano u matici krštenih pa ne znamo daljnje kretanje tih ljudi. Češće se nailazi na krštenja od 2 do 6 osoba odjednom, a ponekad se zajedno krste članovi iste obitelji. Primjerice, 7. prosinca 1608. godine kršteni su Petar, sin Mehmeta i Fatime iz Klisa, njegova žena Magdalena, njihova dva sina Šimun i Ivan te njihove tri kćeri Marta, Katarina i Lucija. ${ }^{41}$

Na temelju dostupnih podataka moguće je utvrditi da je broj krštenih Turaka u matičnim knjigama župe sv. Stošije broj onih Turaka koji su ostali na službi u gradu Zadru, dok je broj svih robova koji su prošli kroz Zadar prema krajnjim destinacijama nepoznat $i$ tek ga treba istražiti.

Zbog neujednačenosti upisanih informacija u maticama krštenih u prvoj i u drugoj polovici 17. stoljeća starosnu dob pokrštenih Turaka u Zadru može se utvrditi za drugu polovicu 17. stoljeća. Najveći udio krštenih Turaka kreće se u rasponu od prve do 30. godine života, što je i logično s obzirom na to da su djeca i mladi robovi bili najtraženiji i na njima su trgovci najbolje zarađivali (Tablica 3 ). ${ }^{42}$

TABlica 3. Pokršteni Turci upisani u matice krštenih po desetljećima prema starosnoj dobi (kada je ona naznačena $M=$ muški spol, $\check{Z}=\check{z} e n s k i$ spol, $A=0-13$ godina; $B=14$ - 20 godina; $C=21-30$ godina; $D=31-40$ godina; $E=41-50$ godina; $F=51-60$ godina $G=v i v^{2}$ od 60 godina; $H=$ godine nisu naznačene)

\begin{tabular}{|c|c|c|c|c|c|c|c|c|c|c|c|c|c|c|c|c|c|c|}
\hline Razdoblje & M & A & B & C & $\mathrm{D}$ & $\mathrm{E}$ & $\mathrm{F}$ & G & $\mathrm{H}$ & $\check{\mathbf{Z}}$ & A & B & $\mathrm{C}$ & $\mathrm{D}$ & E & $\mathrm{F}$ & G & $\mathrm{H}$ \\
\hline $1600 .-1610$ & 16 & / & / & / & 1 & / & $/$ & 1 & 16 & 12 & / & 1 & $/$ & / & 1 & / & 1 & 12 \\
\hline $1611 .-1620$ & 9 & / & / & / & / & / & / & / & 9 & 4 & / & / & / & / & / & / & I & 4 \\
\hline $1621 .-1630$. & 9 & / & / & / & / & / & / & / & 9 & 10 & / & / & / & / & / & / & / & 10 \\
\hline $1631 .-1640$. & 11 & / & / & / & / & / & / & / & 11 & 10 & / & / & / & / & / & / & / & 10 \\
\hline $1641 .-1650$ & 45 & 1 & / & / & / & 1 & / & / & 44 & 40 & 3 & I & 1 & / & / & 1 & 1 & 37 \\
\hline $1651 .-1660$ & 14 & 1 & / & / & / & 1 & / & $/$ & 14 & 13 & / & I & 1 & I & / & 1 & I & 13 \\
\hline $1661 .-1670$ & 2 & 1 & 1 & / & / & 1 & / & / & I & 4 & / & / & / & I & / & / & / & 4 \\
\hline $1671 .-1680$. & 17 & / & 6 & 7 & / & 1 & / & 1 & 2 & 2 & / & l & 1 & I & 1 & 1 & / & I \\
\hline $1681 .-1690$. & 22 & 10 & 6 & 1 & 1 & / & 1 & / & 3 & 51 & 26 & 11 & 7 & 4 & 1 & I & I & 2 \\
\hline $1691 .-1700$. & 16 & 4 & 4 & 7 & 1 & / & / & / & / & 49 & 15 & 10 & 7 & 8 & 4 & 2 & 1 & 2 \\
\hline
\end{tabular}

Izvor: HR-AZDN-43, Zbirka matičnih knjiga i parica matičnih knjiga Zadarske nadbiskupije, župa sv. Stošije - Zadar, matične knjige od 1595. do 1707.

41 Liber VII, fol. 4r-4v. Kumovi su bili: Ivan Jakov Zane, generalni providur; Domenico Tiepolo, zadarski knez; Franjo Cortinari, zadarski kapetan; Leonardo de Menigo, zapovjednik konjice; Ivan Lipomani, zadarski kamerlengo; Vicko Grimani i Tulio Elisio, zapovjednik vojske.

42 Napominjem da u tablici nisu uvršteni pokršteni Turci iz razdoblja 1641. - 1650. za koje ne znamo spol ni starosnu dob, a radi se o 41 osobi. 
Od ukupno 326 upisa u maticama krštenih za Turke i Turkinje pokrštene u Zadru tijekom 17. stoljeća za 259 upisa možemo odrediti mjesta ili zemlju rođenja odnosno tranzitne pravce kojima su turski robovi stizali u Zadar. ${ }^{43}$ Najveći broj pokrštenih Turaka je s prostora Dalmacije, zatim Like, Bosne i Hercegovine, mletačke Albanije, a tek neznatan broj iz ostalih udaljenijih regija. U sljedećoj tablici donose se abecednim redom imena onih mjesta, regija i zemalja iz kojih pokršteni Turci dolaze u Zadar. Pored imena mjesta u zagradama je brojkom naznačeno koliko se puta spominje pojedini grad, selo, regija ili država u maticama krštenih župe sv. Stošije u Zadru tijekom 17. stoljeća (Tablica 4). Treba uzeti u obzir da jedan manji dio imena naselja nije bilo moguće transkribirati bilo zbog nečitkog rukopisa, a ponegdje i zbog netipičnih naziva koje nisam uspio razriješiti.

TABlica 4. Popis gradova, sela, regija i država iz kojih pokršteni Turci dolaze u Zadar

\begin{tabular}{|c|c|c|c|c|}
\hline Dalmacija & Lika & $\mathrm{BiH}$ & $\begin{array}{c}\text { Mletačka } \\
\text { Albanija }\end{array}$ & Ostalo \\
\hline Banići (1) & Bilaj (18) & Banja Luka (2) & Bar (1) & Albanija (1) \\
\hline Benkovac (2) & Boričevac (1) & Bihać (4) & $\operatorname{Drač}(1)$ & Albareale (2) \\
\hline Biljane (1) & Brušane (1) & Bila (1) & Herceg Novi (2) & Anatolija (2) \\
\hline Drniš (1) & Bruvno (1) & Bišće (1) & Risan (2) & Barbaria (3) \\
\hline Islam (4) & Budak (1) & Duvno (1) & Skadar (3) & Bosna (2) \\
\hline Karin (1) & Cernik (1) & Kamengrad (2) & Ulcinj (8) & Calamanta (1) \\
\hline Klis (8) & Dabar (1) & Kašići (1) & / & $\begin{array}{c}\text { Castelli di } \\
\text { Constantinopolli (1) }\end{array}$ \\
\hline Knin (13) & Grab (1) & Ključ (3) & I & Epir (1) \\
\hline I & Gračac (6) & Livno $(6$ & I & Konstantinopol (1) \\
\hline Nadin (7) & Udbina (14) & Mostar (2) & I & Lika (4) \\
\hline Obrovac (3) & Novi (4) & Pliva - Glamoč (1) & I & Požega (1) \\
\hline Poljica (1) & \multirow[t]{2}{*}{ Medak (4) } & \multirow[t]{2}{*}{ Rama (4) } & \multirow[t]{2}{*}{ / } & \multirow{2}{*}{$\begin{array}{c}\text { Seraglio (2) } \\
\text { (Constantinopolli) }\end{array}$} \\
\hline Proložac (1) & & & & \\
\hline $\operatorname{Sinj}(7)$ & Mokrovik (1) & Sarajevo (1) & I & Skoplje (2) \\
\hline Skradin $(5)$ & Novi Dol (1) & Stari Majdan (5) & I & Sopton (1) \\
\hline Strmica (1) & Podlapac (1) & Trebinje (5) & I & Turska (1) \\
\hline Velim (1) & Ribnik (8) & Vakuf (1) & I & Valona (1) \\
\hline Vrana (11) & $\operatorname{Srb}(3)$ & Velika Kladuša (2) & I & Velograd (1) \\
\hline Zemunik (30) & Vrebac (3) & I & I & Vollo (1) \\
\hline
\end{tabular}

Izvor: HR-AZDN-43, Zbirka matičnih knjiga i parica matičnih knjiga Zadarske nadbiskupije, župa sv. Stošije - Zadar, matične knjige od 1595. do 1707.

43 Broj upisa u maticama krštenih ne poklapa se s brojem 397 krštenih Turaka s obzirom na to da postoje upisi s više krštenja odjednom. 
Među relevantnim podatcima najzahtjevnije je razriješiti obiteljsko podrijetlo pokrštenih Turaka u Zadru tijekom 17. stoljeća. S obzirom na to da za neke znamo samo njihova imena i eventualno mjesto u kojemu su rođeni ili iz kojega dolaze, nije nam moguće precizirati njihove obiteljske korijene i rodbinske veze. To otežava i činjenica da se radilo o stalnim migracijama ljudi prema naseljima i regijama za koja izvorno nisu genealoški vezani. $\mathrm{K}$ tomu, ilegalna trgovina robljem pri kojoj se nerijetko mijenjalo ili skrivalo izvorno podrijetlo osoba ${ }^{44}$ dodatno otežava istraživanje podrijetla pokrštenih Turaka. Osobito se to odnosi na upise u matice krštenih u prvoj polovici 17. stoljeća. U drugoj polovici 17. stoljeća svećenici su ažurnije upisivali podatke pa se donosi i veći broj imena i prezimena pokrštenih Turaka, njihovih roditelja, supružnika i rodbinskih poveznica. ${ }^{45}$

\section{TURSKI ROBOVI U MLETAČKIM VOJNIM POSTROJBAMA PREMA MATICAMA KRŠTENIH ŽUPE SV. STOŠIJE U ZADRU U 17. STOLJEĆU}

Važno je napomenuti da su poseban status imali zarobljeni vojnici. Oni nisu smatrani robovima (čak ni osmanski vojnici) i uglavnom su držani radi razmjene. Percipirani su kao slobodni ljudi koji, ako ne budu razmijenjeni, mogu slobodno otići jednom kada plate otkup. No, zarobljeništvo je bilo mukotrpno, a odnos prema zarobljenicima grub kako bi ih se primoralo na što brže plaćanje otkupa. ${ }^{46}$ Mletačka je Republika za plaćanje otkupa ustanovila vlastiti fond, s obzirom na to da je ropstvo smatrano gospodarskom i vjerskom prijetnjom. ${ }^{47} \mathrm{U}$ oporuci kanonika Luke Vlatkovića zapisano je Zadar je bio pritisnut otkupom roblja pa je i sam kanonik za te potrebe ostavio na pet mjesta

44 T. Perinčić MaYhew, Prodaja roblja na Jadranu, 115.

45 U prilogu se donosi tablica upisa u maticama krštenih onih pokrštenih Turaka za koje se navode imena i prezimena oca, majke ili oba roditelja, kao i supružnika krštenika i one koji nam pomažu korelirati pojedine upise. Kod imena krštenika kurzivom u zagradama naznačena su njihova imena prije krštenja.

46 T. PerinČić MaYhew, Prodaja roblja na Jadranu, 115.

47 T. Perinčić Mayhew, Prodaja roblja na Jadranu, 116.; Andrea Pelliza, Il riscatto degli schiavi a Venezia, dostupno online, URL: http://storicamente.org/pelizza_storia_schiavi (zadnje posjećeno 7. lipnja 2016.): Il Senato assicurava complessivamente cento ducati di elemosina ordinaria ogni anno, a Natale e a Pasqua, mentre i notai della Dominante, e piu avanti pure della Terraferma e dello Stato da Mar, venivano obbligati a ricordare ai testatori l'opportunità di destinare una somma al riscatto. Agli inizi del Seicento, infine, venne fondata in città un'apposita confraternita, dedicata alla Ss.ma Trinità, dedita alla raccolta di fondi e all'organizzazione delle pratiche necessarie per operare la «redenzione» degli schiavi, ma sotto il controllo del magistrato. 
u gradu po dvije lire. ${ }^{48}$ Razvidno je da su mnogi Zadrani, neovisno o staležu, oporučno ostavljali dio svog novca za ubožnice i otkup robova s osmanskoga teritorija. ${ }^{49} \mathrm{Tu}$ praksu treba pripisati, između ostalog, i eshatološkom strahu od vječne propasti. ${ }^{50}$

Ni Crkva nije bila benevolentna prema prodaji zarobljenih vojnika $s$ neprijateljske strane. Kongregacija za širenje vjere (Congregazione de Propaganda Fidei) poslala je mletačkom Senatu protestnu notu zbog prodaje Morlaka s osmanskog teritorija u ropstvo, iako su ovi uhvaćeni za vrijeme bitke i kao takvi bili ratni zarobljenici. Generalni providur Petar Valier nastojao je dokazati da ti Morlaci ne samo da su vrlo brzo pušteni na slobodu već su i inkorporirani u mletačke vojne trupe. Neki su služili na galijama, ali kao slobodni veslači. Valier spominje i Turke (muslimane) koji su slobodno prešli na mletačku stranu i prihvatili kršćanstvo kako bi mogli živjeti istinsku vjeru kao slobodni ljudi. ${ }^{51}$

Brza zarada i mogućnost ilegalne prodaje robova uzrokovale su razne zloporabe i prodaju čak i kršćana, većinom djece, iako je to bilo strogo zabranjeno u statutima dalmatinskih gradova. Žrtve tih zloporaba najčešće su bili pravoslavni robovi. Mletačka je Republika reagirala kako bi spriječila tu nezakonitu trgovinu te je generalni providur Pietro Valier 1685. godine donio odluku kojom se pravoslavni zarobljenici trebaju posebno prijaviti kod nadležnih vlasti kako bi imali priliku da se otkupe, a za to se mogao koristiti i državni novac. ${ }^{52}$

Relativno velik broj robova koji su služili na galiji, prisilno ili slobodnom voljom, nalazimo i u maticama krštenih katedralne župe Sv. Stošije u Zadru tijekom 17. stoljeća. Uz njih, nerijetko se spominju i turski robovi koji su kao vojnici služili u mletačkim trupama na istočnoj obali Jadrana. Jedna od najpoznatijih i brojčano najmnogoljudnijih mletačkih postrojba nazivala se Fanti oltramarini, a sastojala se uglavnom od pješačkih jedinica. Uz njih, važne su bile postrojbe tzv. Soldati Albanesi, koji se u vrelima češće spominju tijekom 17. stoljeća.

48 Ivna ANZULOVIĆ, Udaja Uršule Vlatković za Šimu Kukića rečenog Tikulina u Zadru 1681. (Prilog poznavanju života u Zadru i Novigradu krajem 17. i i početkom 18. stoljeća, Zadarska smotra, Zadar, (1-4) 2004., 338.

49 Dana 26. studenoga 1699. godine ostavio je Matej de Dominis (Cimelich) novac za il riscatto de Schiavi. HR-DAZD-31, Bilježnici Zadra, Antonio Itcovich, 1698. - 1715., b. III, svež. VII, br. 13. Kanonik Luka Vlatković oporukom od 13. listopada 1702. godine ostavlja novac za cinque luochi pij ordinarij di questa Città compresa la redenzione de poveri Schiavi lire due p(er) cad(aun)o luoco. HR-DAZD-31, Bilježnici Zadra, Antonio Itcovich, 1698. - 1715., b. III, svež. VII, br. 36.

50 O tome više kod: Zdenka Janeković Römer, Na razmeđi ovog i onog svijeta. Prožimanje pojavnog i transcedentnog u dubrovačkim oporukama kasnoga srednjega vijeka, Otium, 2 (1994.), 3- 15 .

51 T. MaYhew, Dalmatia between Ottoman and Venetian Rule, 263.

52 T. PERINČić MAYHEW, Prodaja roblja na Jadranu, 115. 
Uz njih, važne postrojbe činile su flotile, tzv. Barche armate contro Uscocchi, koje su uglavnom djelovale u vodama sjevernog Jadrana. ${ }^{53}$ Iz matica krštenih katedralne župe sv. Stošije razvidno je da i turski robovi čine dio navedenih postrojbi.

Prvi trag u maticama krštenih katedralne župe Sv. Stošije o turskim robovima na galijama u 17. stoljeću nalazi se u zapisu o krštenju Marije Karla 12. kolovoza 1613. godine, gdje stoji da je dječakov otac Turčin koji služi na galiji Filipa Belega. ${ }^{54}$ Kako su se galije često zaustavljale u Zadru radi opskrbe i liječenja ranjenika i drugih bolesnika, što je nužno utjecalo i na gospodarske prilike u gradu, ${ }^{55}$ tako su brodski zapovjednici i njihovi kapelani koristili povoljan trenutak za izvršenje cjelovitog obreda krštenja nekrštenih robova i ranjenika. To se redovito zbivalo u zadarskoj prvostolnici i uvijek $s$ dopuštenjem zadarskog nadbiskupa, koji je prema važećim kanonskim propisima trebao dati ovlast za krštenje odraslog katekumena, bez obzira na to je li bio rob ili slobodnjak. ${ }^{56}$ Takav je slučaj Meme Kasima, krštenog imenom Ivan, koji je bio član Barche Armate pod zapovjedništvom Pavla Ginnija. ${ }^{57} \mathrm{Krstio}$ ga je kanonik Ivan Mosca u Ospedal delli Albanesi 22. ožujka 1615. godine jer je bio u smrtnoj opasnosti zbog prostrijelne rane na glavi. ${ }^{58}$ Slijede krštenja Turaka s galije Vicka Morosinija, Hasana iz Konstantinopola (Castelli di Costantinopoli), sina Mahmuta i Zaele, starosne dobi oko 48 godina, i Alija ( $A l i)$ iz Afrike, sina Mehmeta i Akpane, starosne dobi oko 27 godina, obojice krštenih imenom Ivan. Krstio ih je 13. svibnja 1674. godine kapelan galije fra Nikola Quercinelli, karmelićanin. ${ }^{59}$ Krštenje Mehmeta, Turčina iz Epira (Grčka), vojnika kapetana Genja (Ghegn) Bardija, krštenog imenom Petar, izvršio je 16. veljače 1675. godine Jerolim Mengo, mansionar i kapelan vojske oltramarina, dopuštenjem zadarskog nadbiskupa Parzaghija. ${ }^{60}$ Netom nakon krštenja, 18. veljače 1675. godine, Petar (Mehmet) je umro te je pokopan u crkvi sv. Šimuna u Zadru, u kojoj su se nalazile grobnice hrvatsko-

53 O tim postrojbama više kod: Lovorka Čoralıć, Nedjeljka BALIĆ Nižıć, Iz hrvatske vojne povijesti - Croati a Cavallo i Soldati Albanesi, njihova bratovština i gradivo o njezinu djelovanju od 1675. godine do sredine XVII. stoljeća, Zbornik Odsjeka za povijesne znanosti Zavoda za povijesne i društvene znanosti HAZU, Zagreb, (24) 2006., 71 - 130.

54 Liber VII, fol. 146v.

55 Vera Graovac, Populacijski razvoj Zadra, Geoadria, 9 (1), Zadar, 2004. 55.

56 Kodeks Kanonskog Prava, 1917, Kan. 744. - Krštenje odraslih treba, ako to labko može biti, prepustiti mjesnom Ordinariju, da ga on sam, ako hoće, ili njegov ovlaštenik podijeli na svećaniji način.

57 Pavao Ginni i Mihovil Kruta, koji se spominju u ovom radu, bili su odvjetci albanskih obitelji i zaslužni sudionici mletačko-turskih ratova na dalmatinskom području, osobito zadarskom, tijekom 17. stoljeća. Usp. L. ČorALIĆ, N. BALIĆ Nižıć, Iz hrvatske vojne povijesti, 74.

58 Liber VIII, fol. 3v, br. 9.

59 Liber XII, neoznačen fol.

60 Liber XII, neoznačen fol. 
albanske vojničke bratovštine sv. Jeronima. ${ }^{61}$ Dana 17. veljače 1667. godine kapelan na triremi (capellanus triremis generalitiae) Ivan Krstitelj de Nardi krstio je Usaima Alija, staroga 19 godina, iz Ulcinja, koji se dugo vremena i svojevoljno pripremao za krštenje (quem quidem Adultum per multum temporis ante ritae cathechizaui et diligenter in rebus Christianae fidei instruxi). Usaim Ali kršten je pod imenom Ivan Krstitelj. ${ }^{62}$ Hasan, rodom iz Skadra, kršten imenom Marko, vojnik guvernatora Mihovila Krute (Crutta) ${ }^{63}$ i Alija, iz Binistrija, kršten imenom Antun, vojnik kapetana Zorzija Mide, kršteni su 6. travnja 1646 . godine. ${ }^{64}$ Pred konac 17. stoljeća u maticama krštenih katedralne župe sv. Stošije zabilježena su još krštenja kćeri i sina Sutore Hasanovića iz Trebinja te kćeri i sina Sime Vulahinovića iz Trebinja, obojice vojnika i galijota kneza pukovnika Zorzija Salamona. ${ }^{65}$

\section{KRŠTENJA TURAKA U SMRTNOJ POGIBELJI}

Uvidom u upise krštenih za razdoblje od 1648. do 1650. godine zamjetan je velik broj krštenja turskih robova u kućama njihovih patrona. Uzrok takvoj praksi leži, između ostalog, u činjenici da je u Zadru tijekom toga razdoblja harala epidemija kuge, paralelno s velikom epidemijom u Šibeniku 1649. godine. ${ }^{66}$ Kakav je bio utjecaj kuge na društvene strukture u Zadru i mentalitet ljudi u to vrijeme, nije dosada istraženo, kao uostalom ni u drugim dalmatinskim komunama. ${ }^{67}$ Zasigurno je ovakav oprez razumljiv s obzirom na to da su Zadrani još uvijek pamtili pogubnost ove strašne zarazne bolesti s početka 17 . stoljeća

61 O bratovštini više kod: Lovorka Čoralıć, „Benemerita Nazione“: Albanski vojnici i časnici u Zadru (16. - 18. stoljeće), Zbornik odsjeka za povijesne znanosti Zavoda za povijesne $i$ društvene znanosti HAZU, Zagreb, (27) 2009., 145 - 146.

62 Liber XI, fol. 193r. Die 17. Februarij 1667. Ego infras:tus licentia Reu:mi D. Dni mei Vicarij Gentis iux.a ritum S.R.E. baptizaui Usainum Ali aetatis suae annorum 19. de Ciuitate Dulcini, natum ex infidelibus Parentibus per fidae prauae sette Mabumetanae; quem quidem Adultum electum per multum temporis ante ritae cathechizaui et diligenter in rebus Christianae fidei interuxi: cui nomen fuit superpositum Joannes Bapta, Patrinus fuit Illmus D. Joannes Franciscus Fantonicus depnti Collateralis Regimini Pontificij. Ego Jo(ann)es Bapt(ist)a de Nardi Capp(ella)nus Triresim Generalitiae.

63 Vidi bilješku br. 19.

64 Liber $X$, fol. $65 \mathrm{v}$.

65 Liber $X I V$, fol. $17 \mathrm{v}-18 \mathrm{r}$.

66 Usp. Angelo DE Benvenuti, Storia di Zara dal 1409 al 1797, Milano, 1944., 150; K. Stošić, Turski robovi iz XVII. vijeka u Šibeniku, 91.

67 Na to je upozorio Gordan Ravančić. Vidi: Gordan Ravančıć, Prilog proučavanju Crne smrti u dalmatinskom gradu (1348.-1353.) - raspon izvorne građe i stanje istraženosti na primjerima Dubrovnika, Splita i Zadra, Povijesni prilozi, 26, Zagreb, 2004., 7 - 17. 
kada je od 6000 stanovnika Zadra, navodno, na životu ostalo svega 2073 ljudi, a 1630. godine je od kuge u samom gradu nastradalo 1000, a u zadarskom okružju 3000 ljudi. Epidemija kuge prouzročila je i veliku smrtnost zadarskog plemstva i 1649. godine. ${ }^{68}$ Bianchi navodi da je zaraza kulminirala 6. lipnja 1649. godine, a 2. veljače 1650. godine održana je u Zadru procesija s kipom sv. Roka u znak zahvale za povlačenje zaraze. ${ }^{69}$

Ovdje se donose izvješća o onim krštenjima turskih robova koja su izvršena u kućama njihovih patrona gdje se izrijekom kao razlog navodi opasnost od zaraze (per contagio) kugom (peste), iako se u mnogim drugim upisima krštenja iz tog razdoblja najčešće koristi izraz zbog opasnosti. ${ }^{70}$ Dana 28 . veljače 1651. godine krštene su Katarina i Marija, Turkinje, u kući zbog toga razloga (per contagio), ${ }^{71}$ zatim 6. travnja 1651. godine Šimun Jozef, sin Alage Černičića iz Klisa i žene mu Zelile, koja je bila Turkinja, a sad je kršćanka imenom Jelena, koja je krštena 7. listopada 1649. godine za vrijeme zaraze. ${ }^{72}$ Dana 23. srpnja 1651. godine don Teodor Zampandi dovršio je svete obrede krštenja nad Katarinom, Turkinjom iz Klisa, koju je krstio kanonik Ivan Ragnetto, primicerij zadarskog Kaptola, 1650. godine u kući Zvane iz Makedonije za vrijeme zaraze. ${ }^{73}$ Dana 30. srpnja 1651. godine dovršio je svete obrede krštenja kanonik i arhiprezbiter zadarskog Kaptola Valerije Ponte nad Memetom, Turčinom iz Drača, koji je bio sluga u kući Sebastijana Pontea, u kojoj je i kršten zbog zaraze. ${ }^{74}$ Dana 31. kolovoza 1656. godine don Jerolim Posedarski dovršio je svete obrede krštenja nad Antunom, Turčinom koji se prije zvao Mehmet, sinom Derviša Vojvode Čagdukovića iz Zemunika. Mehmet je kršten 28. siječnja 1648. godine u kući zbog potrebe (zaraza), krstio ga je don Toma Najčinović, sam je poželio zvati se Antun Bonicelli, a kum mu je bio Karlo Bonicelli. ${ }^{75}$ I mnogi drugi turski robovi kršteni su po kućama svojih gospodara zbog istog razloga. 1409-1797, Zadar, 1987., 399, 406.

69 Carlo Federico BiAnchi, Fasti di Zara, Zadar, 1888., 96.

70 Isti se izraz rabi rjeđe u slučajevima neposredne opasnosti od turskih provala prema gradskim bedemima.

71 Liber $X$, fol. 196 r.

72 Liber $X$, fol. 201r.

73 Liber $X$, fol. 201v.

74 Liber $X$, fol. 203 r.

75 Liber X, fol. 292r. 


\section{UTJECAJ SAKRAMENTALNOG ČINA KRŠTENJA NA DALJNJU SUDBINU TURAKA}

Za bolje razumijevanje društveno-političkih zbivanja u Zadru tijekom 17. stoljeća i uzročno-posljedične veze tih zbivanja s crkvenom hijerarhijom u Zadru od velike su pomoći navodi aktivnog sudionika tih događanja, zadarskog nadbiskupa Minuccia Minuccija (1596. - 1604.). U svojim relacijama ad limina 1599. i 1601. nadbiskup Minucci izvještava papu o Turcima koji prelaze na kršćansku vjeru. Iz relacija se doznaje da početkom 17. stoljeća u Zadar dolaze mnogi Turci različitih službi i obraćaju se na kršćansku vjeru. No, postoje problemi. Grad je siromašan i ne može prikupiti sredstva za njihovo uzdržavanje. Nadbiskup sam nadoknađuje njihove troškove kako najbolje zna, nakon što su katehizirani i pokršteni, ali je suočen s intrigantnom činjenicom da se ti pokršteni Turci ne mogu zadržati u Zadru zbog svoje rodbine i turskih službenika koji negoduju i ne zna kamo bi ih mogao poslati. Zbog toga mnogi koji imaju dobru dušu ne prilaze $\mathrm{k}$ vjeri te se tako gube duše koje su potaknute humanim razlozima napustile nevjernički teritorij (teritorij pod osmanskom upravom). Nadbiskup se nada da bi kanonici mogli doskočiti ovom problemu. ${ }^{76}$ Zasigurno je zadarski kaptol sv. Stošije redovito bio involviran u katehizaciju i pokrštavanje Turaka u Zadru, o čemu svjedoči i kanonik Jerolim Mengo, kapelan vojske oltramarina u Dalmaciji, koji kaže da je mnoge nevjernike obratio i katehizirao u svetoj vjeri. ${ }^{77}$ Kaptoli su, nadalje, ovjeravali isprave o krštenju za one robove koji su iz jedne dalmatinske komune prebacivani u drugu. ${ }^{78}$

U dodatku svoje relacije pod naslovom Del modo di aiutare li Turchi che concorrono a Zara et si vanno riducendo alla Fede Christiana nadbiskup Minucci naglašava da je Turcima koji prelaze na kršćansku vjeru potrebno pomoći iz dva razloga. Prvi je što se oni u Zadru poučavaju vjeri i primaju krštenje, a drugi što ih treba nakon krštenja udaljiti od ovih granica (osmanskog teritorija). Za

76 Alberto Marani, Atti pastorali di Minuccio Minucci Arcivescovo di Zara (1596-1604), Rim, 1970., 50.

77 HR-AZDN-18, Liber Privilegiorum Venerabilis Capituli ecclesiae cathedralis S. Anastasiae, martyris, 1399. - 1818., fol. 9.

78 Razvidno je to iz slučaja Turkinje Ajre, kćeri Alije Balilovića iz Skradina, a žene Osmana Spahirovića. Ona je naime 17. listopada 1694. godine krštena u Šibeniku imenom Lujza. Nakon krštenja prodana je u Zadar gdje je bila ropkinja u kući Ivana Krstitelja Paulotija. Ispravu o krštenju ovjerovio je svojim pečatom šibenski kaptol sv. Jakova, a potpisao je kanonik Jakov Caristo. Dana 3. ožujka 1695. godine zadarski kanonik Jakov Buscarolo dovršio je obrede u katedrali sv. Stošije. Usp. Liber XIII, fol. 111v. 
taj posao nadbiskup od pape traži koju crkvenu nadarbinu i odmah predlaže da to bude nadarbina benediktinske opatije sv. Kuzme i Damjana (sa sjedištem na Ćokovcu na otoku Pašmanu), koja je velika i bogata. Ako bi se ta nadarbina pridodala kaptolskoj masi s obvezom da se 200 dukata godišnje namijeni tom poslu, moglo bi se tim novcem pomoći pokrštenim Turcima i uputiti ih dalje prema Veneciji i Ankoni. Nadbiskup nadalje naglašava da mnogi mletački uglednici u Veneciji rado primaju mlade preobraćene Turke i upućuju ih u razne službe. ${ }^{79} \mathrm{U}$ Veneciji i Ankoni postojale su tzv. Case dei Catecumeni. Takve ustanove tijekom novog vijeka nalazimo diljem Apeninskog poluotoka, rjeđe u drugim gradovima Europe (Lisabon, Krakov). Općenito se u znanstvenim raspravama osnivanje prvih kuća za katekumene u Rimu pripisuje papi Pavlu III. 1543. godine, ali je poticaj i utemeljenje tim ustanovama prvi dao sv. Ignacije Lojolski 1542. godine. ${ }^{80}$ Svrha je tih ustanova bila duhovna i ekonomska pripomoć pri procesu kulturne socijalizacije preobraćenih inovjeraca na kršćanstvo na prostoru Europe, prvenstveno islamske i židovske provenijencije. $^{81}$

Prema zapisima iz matica krštenih župe Sv. Stošije zamjetno je da se stavlja naglasak na katehizaciju i uvođenje u vjeru odraslih (adulti) katekumena prema važećim odredbama Tridentskog sabora. Dana 1. siječnja 1655. godine kanonik Valerije Ponte, arhiprezbiter, krstio je odraslog Turčina Šabana, sina Derviša iz Rakitnice, koji je u tom trenutku bio sluga (seruitore) kneza Franje Posedarskog. Kršten je pod imenom Marko te je prije krštenja bio poučen potrebnim istinama svete vjere. ${ }^{82}$

Ponekad su pokršteni Turci dobili ili zatražili prezime svojih gospodara. ${ }^{83}$ Takva je praksa za roba ili slugu značila mogućnost lakšeg uklapanja u društvo, ali i pravo na sklapanje ženidbe koje je potvrdio i Tridentski sabor, tim više što se mahom radilo o mladim ljudima. ${ }^{84}$ Tako je Ivan Turčin, sluga u kući Jakova Boniricordija, kao kršćanin 19. veljače 1696. godine u zadarskoj katedrali

79 A. Marani, Atti pastorali di Minuccio Minucci, 52 - 53.

80 Fu proprio Ignazio di Loyola a concepire e a realizzare in Italia la cosidetta prima «Casa dei Catecumeni», quella di Roma... Pietro Ioly Zorattini, I nomi degli altri. Conversioni a Venezia e nel Friuli Veneto in età moderna, Firenca, 2008., 31.

81 O tome više kod: Marina CAfFiero, Il sospetto di apostasia. Schiavi Turchi e conversioni di fronte al Sant'Uffizio Romano, Per Rita Tolomeo, scritti di amici sulla Dalmazia e l'Europa centro-orientale (ur. Ester Capuzzo, Bruno Crevato-Selvaggi, Francesco Guida), Venecija, 2014., 289 - 304; Marina CAFfiero, Incontrarsi a Roma. Schiavitù, conversioni e apostasie di musulmani tra Inqusizione e Casa dei catecumeni, „Dimensioni e problemi della ricerca storica“, Roma (2), 2013., 83 - 108.

82 Liber $X$, fol. 262v.

83 Liber X, fol. 292r; Liber XIII, fol. 25r.

84 S. MARConcini, Una presenza nascosta, 104, 113. 
oženio Jelenu Selestrinu iz Kukljice. ${ }^{85}$ S njom je 21. srpnja 1696. godine dobio sina Jakova Dominika, kojeg je u zadarskoj katedrali krstio kanonik Antun Buscarolo 8. kolovoza 1696. godine. ${ }^{86}$ Iako je, u povijesnim okvirima, ropstvo opravdavala državna i crkvena legislativa, ipak u 17. stoljeću učitelji moralne teologije nisu pretjerano htjeli dokazivati da institucija ropstva nije u suprotnosti s naravnim, božanskim i eklezijalnim zakonima. S druge strane, nisu se previše trsili ni dokazati da je oslobođenje robova djelo pobožnosti (milosrđa) opravdavajući, u duhu vremena, takav stav tezom da su robovi slabi, zlih sklonosti i ne previše učeni te bi u slobodi mogli postati lijeni, okrenuti se krađi i završiti u zatvoru ili na galiji. Stoga su iznjedrili nekakav zaključak da bi bilo djelo milosrđa osloboditi roba jedino ako je dobar i može vlastitim radom privređivati za život. ${ }^{87}$

Često su žrtve trgovine robljem bili i kršćani s osmanskog teritorija, među njima i djeca. ${ }^{88} \mathrm{U}$ pravu je T. Mayhew kada kaže da su ta djeca bila ispitivana prije krštenja o njihovim obiteljima i da su svejedno krštena, iako se iz njihovih odgovora moglo naslutiti da su pripadali kršćanskim obiteljima i već bili kršteni.$^{89}$ Nerijetko djeca, zbog opravdanog i razumljivog straha i stresa koje su proživljavali odvođenjem u ropstvo, nisu mogla odgovoriti na postavljana pitanja. U slučaju takve opravdane sumnje da je rob već bio pokršten pristupalo se, kako je razvidno iz zapisa u maticama krštenih, krštenju sub conditione..$^{90}$

Dana 27. siječnja 1674. godine kanonik Juraj Zapić, arhiprezbiter zadarskog Kaptola, dozvolom nadbiskupa Parzaghija krstio je sedam Turaka od kojih dvoje sub conditione, Kurtaliju iz Ulcinja, sina Marka i Mare, starog 30 godina, za kojega se sumnjalo da je mogao biti prije kršten, krštenog imenom Petar, i Ali Balija Belitenkija iz Ulcinja, sina Stefana i Stoje, Turcheschi, ${ }^{91}$ starog 26 godina, krštenog imenom Luka. ${ }^{92}$

Nadbiskup Parzaghi krstio je 5. ožujka 1686. godine sub conditione jednog roba u kući Anzola Ema, zadarskog kneza, starog oko 7 godina, iz mjesta Medak Stošije - Zadar, matična knjiga vjenčanih za godinu 1696., fol. 296v.

86 Liber XIV, fol. 4r.

87 J. Francis Maxwell, Slavery and the Catholic Church, $85-86$.

88 T. MAYhew, Dalmatia between Ottoman and Venetian Rule, 265.

89 T. Perinčić MAYhew, Prodaja roblja na Jadranu, 115.

90 Pojam sub conditione označava uvjetno krštenje odraslih osoba za koje ne postoje dokazi o krštenju, ali postoji opravdana sumnja da su već kršteni. Usp. K. STošıć, Turski robovi iz XVII. vijeka u Šibeniku, 95, 97.

91 Izraz se u maticama rabi za kršćane koji su konvertirani na islam.

${ }_{92}$ Liber XII, neoznačena fol. 
u Lici, po imenu Midriel, sina Nikole Lučića i majke Kaje (Caia), krštena imenom Mihael Anđelo. Kum je bio zadarski kapetan Franjo Pizziol. ${ }^{93}$

Krivo je zaključio D. Klen da je formulu krštenja sub conditione u jednom slučaju pokrštavanja turskog djeteta u Rijeci svećenik Furlanis izmislio. ${ }^{94}$ Naime, krštenje sub conditione stara je praksa Crkve ako postoji opravdana sumnja da je osoba već prije mogla biti krštena. Kako su turski robovi dolazili s područja na kojemu su Osmanlije također utjecali na to da kršćanske obitelji prijeđu na islamsku vjeroispovijest, a mnogi su od njih kasnije dovedeni u ropstvo na mletački teritorij $\mathrm{u}$ dalmatinske komune, krštenja takvih individua su se po važećim odredbama kanonskog prava katoličke Crkve morala održati u formi sub conditione, tim više što su imena njihovih roditelja očito bila kršćanske provenijencije. Uz ovu praksu, Crkva poznaje i tzv. krštenje željom. ${ }^{95}$ Tako je mladi Turčin Jusuf, sin Mehmeta iz Knina, star oko 20 godina, rob u kući Marka Antuna Lantane, prema svjedočanstvu dviju sluškinja večer prije svoj smrti uzeo raspelo u ruke i zaželio biti kršten te se u obzir uzela ta njegova želja. Svećenik Sebastijan Gericeo, septimanar zadarske katedrale, našavši ga u očajnom stanju, nakon što je čuo svjedočanstvo sluškinja, krstio je mladića sub conditione 1. lipnja 1700. godine imenom Zvane. ${ }^{96}$

Krštenja u neposrednoj smrtnoj opasnosti, teškoj bolesti robova ili u drugim teškim okolnostima obavljala su se redovito u kućama njihovih gospodara, uvijek sa svrhom spasenja duše. Pritom se, ako je rob bio u mogućnosti odgovoriti, uvijek pitalo njegovu privolu na krštenje. Ponekad, u slučaju da rob sam nije mogao izraziti želju za krštenjem, a htio se krstiti, pitalo se ukućane koji bi o tome dali svjedočanstvo. Primjerice, 6. rujna 1689. godine svećenik Andrija Caldana krstio je Nezimu, kći Ibrahima Imičiljaševića iz Vakufa, ropkinju staru 11 godina, u kući Petra Morija. Ona zbog teškog zdravstvenog stanja nije mogla odgovarati na svećenikove upite pa su ukućani posvjedočili kako je prije izrazila želju da bude krštena te je tako i učinjeno, a krštena je imenom Margareta. Krsni obredi nisu dovršeni u crkvi jer je djevojčica nakon krštenja ubrzo preminula. ${ }^{97}$

Uhitnim slučajevima djecu su krstile primalje. Tako je 25. siječnja 1687. godine upisano u matici krštenih da je sluškinja Franje Zanchija, imenom Ađise, rodila sina, čiji je otac Suljo iz Majdana, kojega je odmah po porodu krstila primalja u

93 Liber XIII, fol. 13r.

94 D. Klen, Pokrštavanje „turske“ djece u Rijeci, 206.

95 Katekizam Katoličke Crkve, Zagreb, 1994., br. 1258 i br. 1259, 334 - 335.: „...želja za krštenjem, donosi plod krštenja, a da po sebi nije sakrament.; Što se tiče katekumena koji umru prije krštenja, izričita želja da ga prime, sjedinjena s kajanjem za grijehe i s ljubavlju, jamči im spasenje koje nisu mogli primiti po sakramentu.“

96 Liber XIII, fol. 64r.

97 Liber XIII, fol. 52v-53r. 
kući Katarine, žene paruna Jerolima Chirina, a kršten je imenom Andrija. Dijete je nakon toga preminulo. ${ }^{98}$

Ovdje treba razmotriti čin krštenja i s gledišta Turaka. Neosporno je da su turski robovi bili u inferiornom položaju u svakom pogledu (društvenom, gospodarskom, pravnom). Jednako tako stoji činjenica da je u njima postojala nada da će krštenjem postići bolju budućnost ili barem čovječniji tretman unutar nove sredine. Valja naglasiti da je među njima vladalo uvjerenje da krštenje ima moć izliječiti bolesti odnosno osnažiti čovjekovo tijelo. ${ }^{99}$ Okolnosti u kojima su se ti ljudi nalazili svakako su uvjetovale njihov pristup sakramentalnom činu krštenja - slobodnom voljom ili voljom gospodara - bilo zbog vjerskih bilo zbog socijalnih razloga. Svakako, krštenje nije bilo bezuvjetna garancija slobodi i s obzirom na to da su neki gospodari pokrštene Turke nakon krštenja otpuštali kao slobodne ljude, a neki ih i dalje zadržavali u svojoj službi, nije potpuno jasno kako je ta praksa tekla. Samuela Marconcini zaključuje: „Ukoliko bi gospodari oslobodili robove nakon krštenja, i ako bi se to masovno događalo, to bi definitivno značilo kraj ropstva, odnosno društvenu praksu temeljenu na činjenici da bi na taj način nevjernici bili u mogućnosti susresti se Kristovom porukom i zadobiti duhovno spasenje“. ${ }^{100}$

Činjenica da se i crkvena teološka misao po pitanju ropstva sporo razvijala i tek koncem 19. i početkom 20. stoljeća jasno definirala stav suprotan svakom obliku trgovanja ljudima i lišavanju temeljnih sloboda bilo koje osobe ${ }^{101}$ dodatno otežava znanstveni diskurs i nerijetko je uzrokom pristranih motrišta o ulozi Crkve u tom osjetljivom pitanju. Nerijetko se i temeljni pojmovi crkvenog nauka stavljaju $\mathrm{u}$ negativni kontekst, poput spasenja duše kod Klena, ${ }^{102}$ te postaju predmetom kontroverzi u znanstvenim raspravama često otežavajući objektivni pristup problematici. Kada je u pitanju mletački Zadar 17. stoljeća i odnos gospodara prema pokrštenim Turcima, sloboda svakog sluge ili roba ovisila je isključivo o dobroj volji gospodara koji je imao vlast otpustiti i darovati sloboduili zadržati roba u svojoj službi, iako je teoretski bilo zabranjeno kršćanina držati u ropstvu. ${ }^{103}$ Krštenje najčešće nije značilo potpunu slobodu, osim u rijetkim slučajevima i najčešće od strane crkvenih službenika u Zadru, što je zamjetno i u drugim dalmatinskim komunama. ${ }^{104}$

98 Liber XIII, fol. 24r.

99 S. Marconcini, Una presenza nascosta, 107.

100 S. MARConcini, Una presenza nascosta, 107.

101 J. Francis Maxwell, Slavery and the Catholic Church, $88-115$.

102 D. KLEN, Pokrštavanje „turske“ djece u Rijeci, 203.

103 Usp. K. STošı́, Turski robovi iz XVII. vijeka u Šibeniku, 97.

104 Primjerice, K. Stošić navodi kako su neki Ivan te Antun, vojnik namjesnika Rastellija, „dobili slobodu u biskupskoj kancelariji“. K. STošIĆ, Turski robovi iz XVII. vijeka u Šibeniku, 98. 


\section{TKO SU BILI „GOSPODARI“ ROBOVA U ZADRU?}

Sluge i sluškinje iz redova turskih robova kupovali su svi dobrostojeći staleži u Zadru. U maticama krštenih tako se u svojstvu gospodara spominju generalni providur, zadarski knez i kapetan, zadarski kamerlengo i kaštelan, pripadnici mletačke vojske, serdari, pripadnici duhovnog staleža, plemići, pučanigrađani, imućniji obrtnici i članovi intelektualnih skupina (liječnici, ljekarnici, odvjetnici...).

Kako se u 17. stoljeću nastavlja proces propadanja plemstva u Zadru, a do izražaja dolazi jačanje pučana, trgovaca, obrtnika i intelektualnih djelatnika koji se polako bogate (liječnici, ljekarnici, učitelji, odvjetnici, duhovne osobe), ${ }^{105}$ ti novi pripadnici bogatijeg društvenog sloja također su angažirali sluge i robove, koji su uglavnom bili pomoćnici u trgovinama (giovane di bottegha). ${ }^{106}$ U maticama krštenih župe sv. Stošije ističe se ime zadarskog obrtnika Ivana Krstitelja Scartinija, proizvođača kotlova, u čijoj je kući tijekom 1690. i 1691. godine u nekoliko navrata zbog potrebe (per necessità) kršteno troje turskih robova, maloljetnika do 14 godina, koji su nakon krštenja preminuli. ${ }^{107}$ Može se iz navedenoga zaključiti da su zabrani držanja kršćanina u ropstvu pojedini gospodari robova doskočili izbjegavanjem njihova pokrštenja sve do trenutka neposredne smrtne opasnosti.

Serdar Stojan Smiljanić držao je ropkinju Turkinju imenom Ajre, staru oko 27 godina, kćer Alije Pložanina iz Ribnika u Lici i žene mu Kadire. Krštena je 31. ožujka 1687. godine imenom Marija. ${ }^{108}$ Iz matica je zamjetno da su ropkinje nerijetko morale udovoljavati i putenim prohtjevima svojih gospodara. Navodimo primjer kneza Karla Benje (Begna) koji je sa svojom sluškinjom Jeronimom, nekad Turkinjom, a sada kršćankom, začeo dijete koje je kršteno 24. prosinca 1694. godine pod imenom Lukrecija Antonija, a u maticama je zavedena kao nezakonita kći (figliuola naturale). ${ }^{109}$

Iako je iz zapisa u maticama krštenih zamjetno da su robove mahom držali pripadnici zadarskih građanskih elita, nerijetko su robove kupovali i Morlaci, kao i imućniji zemljoposjednici ili najamnici zemlje te zadarski obrtnici. Tako je 9. travnja 1690. godine don Antun Buscarolo krstio Kadiru, kćer Horuza Kovačića i Pulije iz Islama, imenom Jelena, koja je bila ropkinja u kući Bile Dekovića,

105 Lovorka Čoralić, Ivana Prijatelj Pavičić, Građanske obitelji Arvatini i Cavaletti, Zbornik odsjeka za povijesne znanosti Zavoda za povijesne i društvene znanosti HAZU, Zagreb, 26 (2008), 88.

106 T. Raukar, I. Petricioli, F. Švelec, Š. Peričić, Zadar pod mletačkom upravom, 393.

107 Liber XIII, fol. 62r; fol. 65r; fol. 68v; fol. 84v.

108 Liber XIII, fol. 26r.

109 Liber XIII, fol. 108v. 
Morlaka nastanjenog u Bokanjcu. ${ }^{110}$ Isti je svećenik, ovaj put u svojstvu kanonika, krstio 21. rujna 1695. godine mladu Turkinju Zahiju, staru oko 13 godina, iz Bilaja, nepoznatih roditelja. Krštena je imenom Jelena, a bila je ropkinja Tome Gvozdena (Guosdin), stanovnika Malpage (Dračevac Zadarski). ${ }^{111}$ I mali Muho, star oko 10 godina, sin Mumina Odobašića i Zahije iz Bilaja, bio je rob Mihovila Kužinovića iz Sv. Filipa i Jakova. Kršten je 15. listopada 1696. godine u Zadru gdje je trenutno bio nastanjen kod Franje Zanchija. ${ }^{112}$ Kako se od 1686. do 1700. godine ime Franje Zanchija, koji je netom preselio iz Bergama u Zadar, ${ }^{113}$ često spominje u svojstvu vlasnika turskog roblja i onoga kod koga su robovi na čuvanju, može se zaključiti da je Zanchi na neki način bio involviran u trgovinu robljem.

Dana 31. kolovoza 1684. godine don Antun Buscarolo, dozvolom nadbiskupa Parzaghija, krstio je dijete roba po imenu Alija, starog oko 3 godine, nepoznatih roditelja, kojega je kupio pravoslavac Rade Filipović iz Budina, a kršten je imenom Ivan. ${ }^{114}$

I zadarski nadbiskup kao i neki kanonici i svećenici uzimali su sluge u svoje kuće. Ne znamo je li Stjepan Turčin, kršten 22. ožujka 1647. godine, bio sluga u biskupovoj kući u Zadru, ali ga je tamo, zbog potrebe, krstio don Ivan Ragnetto, dozvolom vikara. ${ }^{115}$ Sa sigurnošću se može ustvrditi da je zadarski kanonik Ivan Rupinić (Rupineo) imao sluge (robove) u svojoj kući. Dana 12. siječnja 1686. godine katedralni župnik Antun Bolognese, dozvolom nadbiskupa Parzaghija, krstio je u kući zbog neposredne opasnosti Turčina starog oko 20 godina, koji je bio rob (schiavo) u kući zadarskog kanonika Ivana Rupinića, i to pošto je uveden u otajstva vjere. Turčin se zvao Šaban, sin Sale i Kumije iz mjesta zvanoga Sopton, a kršten je imenom Ivan Marija. Krsni su obredi dovršeni 15. lipnja 1686. godine uz asistenciju Petra Bonicellija i Aleksandra Cavalierija. ${ }^{116}$ Istoga je Ivana kanonik Rupinić oslobodio ropstva pa je u tom slučaju krštenje osim spasenjskog učinka na dušu polučilo i učinak na potpunu slobodu i stjecanje građanskih prava nakon čega je Ivan zasnovao vlastitu obitelj. Naime, u zapisu

110 Liber XIII, fol. 60v-61r.

111 Liber XII, fol. $115 \mathrm{r}$.

112 Liber XIII, fol. 5v-6r.

113 L. Čoralić, I. Prijatelj Pavičıć, Građanske obitelji Arvatini i Cavaletti, bilj. 30, 98.

114 Liber XII, neoznačena fol.

115 Liber $X$, fol. 100r.

116 Liber XIII, fol. 11r. Pojam dovršenje krsnih obreda zasigurno ovdje pretpostavlja krštenje obavljeno uslijed nekih nepovoljnih uvjeta (ratne opasnosti, epidemije...) bez dodjele svetih ulja i izostavljanja cerimonija i egzorcizama, što se u takvim slučajevima obavljalo naknadno. Usp. K. STošıć, Turski robovi iz XVII. vijeka, 91. 
od 28. listopada 1695. godine stoji da je dana 28. listopada 1695. godine kršten Šimun, sin Ivana Turčina, koji je postao kršćanin, a služio je u kući kanonika Ivana Rupinića, i njegove zakonite žene Margarete, kćeri Mateja Krstića Varošanina. ${ }^{117}$

Kanonik Rupinić ponovno je uzeo za sluškinju tursku djevojčicu Buđu, staru oko 8 godina, kćer Ređepa Lončara i Kome iz Ribnika, koja je krštena 17. lipnja 1688. godine imenom Doroteja Katarina. ${ }^{118}$ Kanonik don Ivan Tanzlingher Zanotti imao je roba od 6 godina imenom Bale, sina Jusufa Glavića i Mejre iz Knina, krštenog 27. veljače 1689. godine imenom Mihovil Anđelo. U kući zadarskog nadbiskupa Priulija služila je 1698. godine Turkinja imenom Safila, kći Ibrahima Čenavordića i Artiđe Mustafić iz Bihaća. Krštena je 29. ožujka 1698. godine imenom Marija. ${ }^{119}$ Dana 15. lipnja 1688. godine kršstena je sub conditione djevojčica zvana Gvozdena, sluškinja u kući don Trifuna Fidatisa, po čuvenju moguće kći Rave i Stošije iz Udbine, krštena imenom Antonija. ${ }^{120}$

Ponekad su zadarske udovice posvojile tursku djecu, prvenstveno onu za koju se smatralo da su dovedena u ropstvo iz kršćanskih obitelji (figliuola della carita, figliuola dell'anima). Tako je Katarina, žena pok. Nikole Marcocija Spizze iz Albanije, posvojila djevojčicu imenom Smiljana, iz Krbave, staru oko 7 godina koja nije znala reći imena svojih roditelja, a krštena je 14. lipnja 1686. godine imenom Stošija Ana. ${ }^{121}$ Arina, žena pok. guvernatora Zorzija Villanuove, usvojila je turskog dječaka starog oko 3 godine koji je kršten 5. svibnja 1687. godine imenom Ivan Krstitelj. ${ }^{122}$

I osuđenici na galiju, kao i ostali turski pritvorenici, kršteni su u slučaju smrtne opasnosti. Dana 23. prosinca 1686. godine zbog smrtne je opasnosti u bolnici za osuđenike kršten Turčin Bajro iz Ulcinja, sin Osmana i Bilomerije Amheder, imenom Anzolo. On je prije toga bio osuđen na galiju. ${ }^{123}$ Dana 1. lipnja 1648. godine kanonik Šime Mosca krstio je Zvanu, Turčina, koji je bio u pritvoru kod Filipa Žarkovića.

Među pokrštenim turskim robovima bilo je i pripadnika uglednijih obitelji s osmanskog teritorija. Ropkinja u kući Dominika Albergini-Sageca, Sale, krštena imenom Katarina, starosne dobi oko 18 godina, bila je kći Hasana,

117 Liber XIII, fol. $115 \mathrm{v}$.

118 Njoj je kanonik Rupinić 28. veljače 1699. godine oporučno ostavio 50 dukata: Lascia a Dorotea sua Schiaua battezata ducatti cinguanta... HR-DAZD-31, Bilježnici Zadra, Antonio Itcovich, 1698. 1715., b. III, svež. VII, br. 2.

119 Liber XIII, fol. 31r.

120 Liber XIII, fol. 39v.

121 Liber XIII, fol. 16v.

122 Liber XIII, fol. 27r (II). U ovoj matici krštenih dvije su stranice označene brojem 27.

123 Liber XIII, fol. 22v. 
kapetana grada Bihaća i Ajre. ${ }^{124}$ U ropstvo je tako dovedena i Anka, kći Omera Zenkovića, zapovjednika Like i Krbave, i njegove žene Fate, starosne dobi oko 23 godine. Anka je krštena 13. kolovoza 1692. godine po imenu Jeronima, a kao ropkinja je služila u kući zadarskog kneza Karla Benje (Begna). ${ }^{125}$ I žena ličkog harambaše Šabana Berića, Aska, kći Šabana Kovačevića i Ajne iz Like, završila je u ropstvo u kući Stjepana Piazze. Krštena je pod imenom Anzola 15. ožujka 1693. godine. ${ }^{126}$

Osobito se ističe djelovanje kapucina fra Bartolomeja iz Verone u procesu pokrštenja Turaka u Zadru. ${ }^{127}$ Dana 10. svibnja 1647. godine don Jeronim Polini dovršio je crkveni obred krštenja nad Bartolom, Turčinom iz Nadina, koji je zbog potrebe kršten u kući fra Bartolomeja kapucina. ${ }^{128}$ Isti fra Bartolomej krstio je 16. rujna 1647. godine Ahmeta, Turčina, sina Derviša Livakovića i Kadize, pod krsnim imenom Bartol. ${ }^{129}$ Kako je razvidno iz istraživanja D. Madunića, fra Bartolomej krstio je više od 200 Turaka, što mjesni predstavnici mletačke vlasti nisu benevolentno gledali te su, štoviše, opstruirali njegovo djelovanje. ${ }^{130}$

\section{SLOBODNI TURCI I SVOJEVOLJNI PRISTUP KRŠTENJU}

Nisu svi pokršteni Turci tijekom 17. stoljeća došli u Zadar kao roblje. Don Jeronim Polini je 22. ožujka 1647. godine krstio Josipa, Turčina, kojeg je pronašla Katarina, žena Zvone Arbanasa. ${ }^{131}$ Dakle, nije bio prodan, već vjerojatno ostavljen u gradu ili na neki način odvojen od svoje obitelji.

U zapisu o krštenju mladog Turčina Omera iz Knina, starog oko 26 godina, sina Mustafe Atlića i Sibile navedeno je da Omer nije bio obvezatan ići u ropstvo, a u Zadru se nalazio u kući svoga brata ${ }^{132}$ koji se također obratio na kršćanstvo. Omer je kršten 31. kolovoza 1692. godine imenom Ivan. ${ }^{133}$ Nadalje, 1. siječnja

\footnotetext{
124 Liber XIII, fol. 29v.

125 Liber XIII, fol. 85 r.

126 Liber XIII, fol. 92r-92v.

127 O djelovanju kapucina fra Bartolomeja iz Verone u Dalmaciji vidi više kod: M. BOGOVIĆ, Katolička Crkva i pravoslavlje, 8, 32 - 33, 35, 167, 169.

128 Liber $X$, fol. 103 r.

129 Liber $X$, fol. $113 \mathrm{v}$.

130 D. MAdunić, Conversion Under the Threat of Arms, 2 - 3.

131 Liber $X$, fol. 98v.

132 Ne navodi se ime Omerova brata kod kojeg je stanovao. U maticama krštenih upisana su još dva sina Mustafe Atlića i Sibile - Nukan, kršten 13. lipnja 1689. godine imenom Antun Jerolim, i Osman, kršten 28. ožujka 1692. godine imenom Aleksandar.

133 Liber XIII, fol. 85 r.
} 
1696. godine pristupila je svojom voljom krštenju mlada Turkinja Lata (Late), kći Bećira Beščirevića i Fatime iz Repca, uzevši ime Jelena. Krštenju su je priveli njezina majka i brat koji su nekoliko godina ranije kršteni u Zemuniku ${ }^{134} \mathrm{I}$ u maticama krštenih drugih dalmatinskih komuna zapisana su svjedočanstva o svojevoljnom prihvaćanju krštenja turskih robova izražena pojmovima religionem christianum cupientes, sponte ac libere i slično. ${ }^{135}$

\section{ZAKLJUČAK}

Turbulentna događanja u zadarskom zaleđu tijekom 17. stoljeća uzrokovana čestim ratnim sukobima mletačkih i osmanskih snaga te uzajamno korištenje novopridošlih stanovnika Morlaka s jedne i druge strane razgraničenja, kao i činjenica novonastalog "gerilskog" načina ratovanja u kojemu se stanovništvo osvojenog teritorija odvodilo u zarobljeništvo i postajalo predmetom trgovine robljem, uzrok je intenziviranju te trgovine tijekom razmatranog razdoblja. Mletačka je Republika trgovinu robljem nastojala držati pod kontrolom pri čemu je donesena pravna odredba da se robovi s turskog teritorija imaju pokrstiti prije prodaje. Više je razloga takvoj odluci. Prvi je religiozno uvjerenje o jedinoj pravoj vjeri - kršćanstvu, pri čemu su pripadnici drugih religija smatrani nevjernicima (infedeli). Nadalje, zarobljenim Turcima krštenje je trebalo garantirati slobodu i postupno prihvaćanje u lokalnu zajednicu. No to se nije uvijek događalo i u mnogome je zapravo ovisilo o dobroj volji njihovih gospodara. Crkva je poticala takvu praksu, ali gledano u povijesnim okvirima, nije znatnije utjecala na raspravu o pitanju opravdanosti ropstva. Štoviše, zauzimala je mlaki stav prema toj problematici. Tek će se koncem 19.i početkom 20. stoljeća teološki nauk o ropstvu jasnije formulirati i konačno osuditi ropstvo kao potpuno neprihvatljivo i moralno nedopustivo. $\mathrm{K}$ tomu, svakako $\mathrm{u}$ obzir treba uzeti i naznačeni interes Mletačke Republike za ljudskom snagom na galijama te sukladno tomu i perfidan odnos mletačkih službenika vlasti prema crkvenim službenicima o pitanju pokrštenja Turaka, što baca dodatno

134 A di p(rim)o Genaro 1696 Io Don Ant(onio) Buscarolo Can(onico) Curato del Duomo di Zara con licenza dell' Ill(ustrissi)mo et R(everenedissi)mo Mon(signo)r Vittorio Priuli Arciu(escou)o di Zara ho battezzato una Turca d'anni 17 in circa la quale p(er)uene alla deuotione con sua madre et un suo fratello li quali gia anni fa furono battezzati a Zemunico da quel paroco, lo quale prima fu instrutta nelli Dogmi della Santa Fede quale nel mahumetismo si chiamaua p(er) nome Late figliuola di Becir Bescireuich, madre Fatime ambe doi Turchi dal loco detto Rebaz parte Turbesco, alla quale fu posto nome Elena, fu patrina Anna Consorte di Caporal Steffano Cumbattouich Pupich. Liber XIII, fol. 117r.

135 K. STošıć, Turski robovi iz XVII. vijeka u Šibeniku, 91. 
svjetlo na razumijevanje problematike te nužno nameće potrebu njezine dublje analize radi boljeg utvrđivanja svih okolnosti i stvarnih povijesnih činjenica o tome pitanju.

U Zadru je tijekom 17. stoljeća pokršteno sveukupno 397 Turaka, ali to zasigurno nije konačan broj Turaka koji su prošli trgovištem roblja zadarske komune. Oni koji su kršteni u Zadru najčešće su ostajali u službi zadarskog plemstva i bogatijeg sloja građana-pučana. Neki od gospodara držali su se kršćanskih uvjerenja te su nakon krštenja oslobodili svoje sluge, neki su to činili prije smrti u svojim oporukama, a veliki broj gospodara držao je pokršteno roblje i dalje pod svojom vlašću. Činjenica da su neki Turci svojevoljno prihvatili kršćansku vjeru, a neki neposredno pred samu smrt, bilo vlastitom ili voljom gospodara, otvara prostor daljnjem istraživanju te problematike dijelom iznesene u ovom skromnom prilogu. 
Prilog 1. Tablični prikaz dostupnih imena i prezimena roditelja i supružnika krštenih Turaka prema maticama krštenih župe sv. Stošije u Zadru u 17. stoljeću.

\begin{tabular}{|c|c|c|}
\hline Datum krštenja & $\begin{array}{c}\text { Podatci o imenu i prezimenu krštenikovih } \\
\text { roditelja }\end{array}$ & Krštenik/-ica/-ici \\
\hline 3. kolovoza 1609. & Pavao Rapanović i Kata Turkinja iz Zemunika & Ivan i Jakov \\
\hline 7. studenoga 1610. & Hasan i Rasima Ručijević iz Vrane & Šimun \\
\hline 2. veljače 1611 . & Mustafa Alijić i Sađa iz Sinja & Helena (Runeha) \\
\hline 2. veljače 1611 . & Mustafa Alijić i Runeha Sozačinić & Katarina (Zulfija) \\
\hline 27. veljače 1611 . & Kurtalija Kafrizijić i Samera iz Vrane & Vicko (Hussein) \\
\hline 12. srpnja 1615. & Mustafa Tušanović i Rasima & Ivan (Hasan) \\
\hline 7. veljače 1626. & Musa Černičić i Terzika iz Klisa & Magdalena \\
\hline 26. travnja 1627. & Osman Hafunijević i Ćamila & Ivan (Mahmet) \\
\hline 21. prosinca 1627 . & $\begin{array}{l}\text { Šaban Osmanović i Orsola, kći Bokije } \\
\text { Cingana iz Vrane }\end{array}$ & Magdalena \\
\hline 22. listopada 1628. & Himbrajim i Alema Jelačić iz Mostara & Marija (Đenisuma) \\
\hline 26. rujna 1629. & Safet Jovančević i Nubekara & Katarina (Binasa) \\
\hline 30. prosinca 1629. & Katarina, kći Mustafe Velage iz Klisa & Margarita \\
\hline 6. listopada 1630. & Husaim Milanović i Elena iz Mostara & Katarina (Rasima) \\
\hline 13. veljače 1637 . & Kurta i Katarina Poropatić iz Biljana & Ivan \\
\hline 10. svibnja 1637. & Mihovil Šarić, turski podložnik i Margarita & Juraj \\
\hline 12. listopada 1645 . & Hider Kakarić i Hana iz Skadra & Julije (Omer) \\
\hline 6. siječnja 1647. & Čuzo Menigrić i Đulsa iz Islama & $\begin{array}{l}\text { Toma, Ivan, Franjo, } \\
\text { Zorzi }\end{array}$ \\
\hline 16. rujna 1647. & Derviš Livaković i Kadiza & Bartol (Ahmet) \\
\hline 27. prosinca 1648 . & Mustafa Mehić i Bisada & Jeronima (Agija) \\
\hline 19. srpnja 1651 . & Alaga Černičić i Zelila iz Klisa & Šimun Jozef \\
\hline 5. ožujka 1656. & Husain Hasanović iz Skadra & Ivan Antun (Mustafa) \\
\hline 5. ožujka 1656. & Bećir Alendaković iz Livna & Ivan Franjo (Mehmet) \\
\hline 18. travnja 1656. & Mehmet Turčikapić iz Velima & Marko \\
\hline 31. kolovoza 1656. & Derviš Vovoda Čagduković iz Zemunika & Antun (Mehmet) \\
\hline 16. rujna 1656. & Ahmet Okčić iz Nadina & Klara (Kerima) \\
\hline 1. travnja 1663. & Hasan Efendija Harkotić i Fatima iz Sinja & Marija (Fata) \\
\hline 10. rujna 1664. & Satija Skočić i Ajša iz Ostrovice & Katarina (Zehra) \\
\hline 3. ožujka 1673. & Pile Cingan iz Banja Luke & Augustin (Sabin) \\
\hline 9. srpnja 1675. & Zule Terezić iz Bilaja & Ivan (Husein) \\
\hline 22. srpnja 1675 . & Mehmet Bosnić i Ajša iz Bilaja & Augustin Nikola $(A l i)$ \\
\hline 22. srpnja 1675. & Alija Meduljica i Burkehana iz Like & Antun (Omer) \\
\hline 14. studenoga 1675 . & Ibrahim Čotić iz Bilaja u Lici & Helena (Zabija) \\
\hline 25. travnja 1685. & $\begin{array}{l}\text { Muhamed Apić i Taida Kurtović iz Metka } \\
\text { (Medak) }\end{array}$ & Orsola Margareta (Ava) \\
\hline 20. siječnja 1686. & Rezeb Bašić i Neala iz Srba & Margarita \\
\hline 3. veljače 1868 . & Mustafa Derderović iz Benkovca & Anzola Marija (Safa) \\
\hline
\end{tabular}




\begin{tabular}{|c|c|c|}
\hline Datum krštenja & $\begin{array}{c}\text { Podatci o imenu i prezimenu krštenikovih } \\
\text { roditelja }\end{array}$ & Krštenik/-ica/-ici \\
\hline 5. ožujka 1686. & Nikola Lučić i Kija iz Metka (Medak) u Lici & Mihael Anđeo (Midriel) \\
\hline 19. lipnja 1686. & Mahmud Salija Ormanić i Safija iz Udbine & Jelena Marija (Lejla) \\
\hline 18. listopada 1686 & $\begin{array}{l}\text { Omer Čuturgurdić i Zahira, kći Mustafe, iz V. } \\
\text { Kladuše }\end{array}$ & Marija \\
\hline 27. listopada 1686. & Daćin Gredić iz Ribnika & Katarina (Fata) \\
\hline 30. listopada 1686. & Bećir Paginović i Muhiba iz Ribnika u Lici & (Saliha) \\
\hline 2. studenoga 1686 & $\begin{array}{l}\text { Karam beg Glumčević i Zahira, sestra Dizdara } \\
\text { iz Graba, oboje iz Udbine }\end{array}$ & Margarita (Hajra) \\
\hline 22. prosinca 1686. & Haršlabić Nemijić i Kerima & Katarina $(S a f a)$ \\
\hline 22. prosinca 1686 . & Alija Šeuklić i Kumrija iz Bilaja & Katarina $($ Rejha $)$ \\
\hline 1. siječnja 1687. & Omer Hijić i Semina iz Srba & Toma (Selman) \\
\hline 1. siječnja 1687. & Omer Jerković i Fatima iz Prološca & Mandalina (Saliha) \\
\hline 5. ožujka 1687. & Idris Đulić i Kadira, Muratova rodica, iz Bilaja & Pavao Gritti (Mumin) \\
\hline 25. ožujka 1687. & Atila Banić Odopaša i Ajra, iz Banića & Marija (Saliha) \\
\hline 31. ožujka 1687. & Alija Pložanin i Kadira iz Ribnika & Magdalena $(A j a)$ \\
\hline 20. travnja 1687 & Alija Pložanin i Kadira iz Ribnika & $\begin{array}{l}\text { Antonija Margareta } \\
(\text { Bega })\end{array}$ \\
\hline 21. travnja 1687. & Mujo Desderonić i Kanita iz Metka (Medak) & Katarina $($ Reba $)$ \\
\hline 29. svibnja 1687. & Memija Širić i Mahala iz Novog Dola u Lici & Antun (Sefer) \\
\hline 17. kolovoza 1687. & Hasan, kapetan grada Bihaća i Ajra & Katarina (Sali) \\
\hline 20. rujna 1687 . & Mazo Mičinović iz Novog u Lici & Katarina (Esma) \\
\hline 8. listopada 1687. & Sadih Ferihija i Seliha iz Novog u Lici & Zvane (Osman) \\
\hline 5. studenoga 1687. & Alija Sekuljić i Begzada Kapić iz Udbine & Katarina (Kadira) \\
\hline 9. studenoga 1687 . & Ahmet Čehajić i Fatima iz Sinja & Magdalena (Reba) \\
\hline 18. prosinca 1687. & $\begin{array}{l}\text { Fazlija(suprug krštene) Kurspahić iz Đeleza } \\
\text { (suprug krštene) }\end{array}$ & Margareta $(A j s ̌ a)$ \\
\hline 19. travnja 1688. & $\begin{array}{l}\text { Alija Tarifović i Zahija; Hasan (suprug) } \\
\text { Marković iz Novog }\end{array}$ & Margareta $($ Azra $)$ \\
\hline 17. lipnja 1688. & Ređep Lončar i Koma iz Ribnika & $\begin{array}{l}\text { Doroteja Katarina } \\
\text { (Buda) }\end{array}$ \\
\hline 2. veljače 1689 . & Sale Sahinović i Osma iz Bilaja & Magdalena $(A j \check{s} a)$ \\
\hline 20. veljače 1689 . & Sale Serbizić i Sava iz Knina & Katarina (Mersa) \\
\hline 27. veljače 1689 . & Jusuf Glavić i Mejra iz Knina & Mihael Anđeo (Bale) \\
\hline 6. ožujka 1689. & $\begin{array}{l}\text { Vlah Memonić i Vuka, kći Hazihanovića iz } \\
\text { Sinja }\end{array}$ & Andela (Fata) \\
\hline 7. ožujka 1689. & Halil Hodža Nonbegović (suprug) iz Rame & $\begin{array}{l}\text { Anzola Izabela Ana } \\
(\text { Emina })\end{array}$ \\
\hline 18. svibnja 1689. & $\begin{array}{l}\text { Muho Serbečić i Fatisa, kći Hazamita Parića } \\
\text { iz Duvna }\end{array}$ & $\begin{array}{l}\text { Frančeska Perina } \\
\text { Margareta (Hajra) }\end{array}$ \\
\hline 12. lipnja 1689. & $\begin{array}{l}\text { Ahmet Hesderović i Rebiza Paravinja iz } \\
\text { Ribnika }\end{array}$ & Zvane (Mujo) \\
\hline
\end{tabular}




\begin{tabular}{|c|c|c|}
\hline Datum krštenja & $\begin{array}{l}\text { Podatci o imenu i prezimenu krštenikovih } \\
\text { roditelja }\end{array}$ & Krštenik/-ica/-ici \\
\hline 13. lipnja 1689. & Mustafa Atlić iz Knina i Sibila iz Skoplja & Antun Jerolim (Nukan) \\
\hline 14. lipnja 1689. & Zahir Husić i Saliha iz Like & Antun Filip (Omer) \\
\hline 6. rujna 1689. & Ibrahim Imičiljašević iz Vakufa & Margareta (Nezima) \\
\hline 24. rujna 1689. & $\begin{array}{l}\text { Mumin Križlja i Kama, kći Horuza Nurića iz } \\
\text { Udbine }\end{array}$ & Franjo (Musta) \\
\hline 13. prosinca 1689. & $\begin{array}{l}\text { Mustafa Hemijer Spahija iz Knina i Saliha, kći } \\
\text { Ibre Kozopdže }\end{array}$ & Marija \\
\hline 15. siječnja 1690. & Metis Franjić i Kamara iz Vrebca & Lucija $(A j \check{s} a)$ \\
\hline 29. siječnja 1690. & Mehmet Kažapović i Hurma iz Bilaja & Katarina (Sebija) \\
\hline 6. veljače 1690. & Mehmet Kejhanović i Zahira iz Ribnika & Jerolima Lucija (Fađa) \\
\hline 16. veljače 1690 . & $\begin{array}{l}\text { Memet Smerdeljević iz Gračaca; Muhamed } \\
\text { (suprug) Jarenić iz Gračaca }\end{array}$ & Magdalena (Saliha) \\
\hline 16. veljače 1690 . & Muhamed Jarenić i Saliha iz Gračaca & Katarina (Fata) \\
\hline 9. travnja 1690. & Horuz Kovačić i Pulija iz Islama & Jelena (Kadira) \\
\hline 1. svibnja 1690. & $\begin{array}{l}\text { Šaban Marketinović i Ava, kći Homeina } \\
\text { Osmana Dobarčića, iz Budaka }\end{array}$ & Katarina (Đula) \\
\hline 7. rujna 1690. & Zafer Subašić i Fatima iz Bilaja & Santa (Kamara) \\
\hline 4. studenoga 1690. & Muho (suprug) Zorbačić iz Knina & Katarina $(F a t a)$ \\
\hline 4. veljače 1691 . & Osman Smerdeljević i Rahima iz Obrovca & Zvane (Alija) \\
\hline 1. travnja 1691. & Ibrahim Spahić i Anica iz Knina & Katarina (Fatima) \\
\hline 17. rujna 1691. & Alibeg Alagić i Merima iz Sinja & Barbara (Hajra) \\
\hline 14. siječnja 1692. & Durak Hodža i Fatima iz Cernika & Katarina (Rabima) \\
\hline 12. veljače 1692 . & Ibrahim Alihodžić i Kerima Knina & Katarina (Sale) \\
\hline 6. ožujka 1692. & Dizdar Alija i Mersa iz Majdana & Laura Apolonia (Đula) \\
\hline 27. ožujka 1692. & Selman Hubijarević i Mersa iz Gračaca & Marko $(A l i)$ \\
\hline 28. ožujka 1692. & Mustafa Atlić i Sibila iz Knina & Aleksandar (Osman) \\
\hline 31. srpnja 1692. & $\begin{array}{l}\text { Alija Sfatić i Ava, kći Osmana Klunčevića iz } \\
\text { Bruvna }\end{array}$ & Ivan Krstitelj (Baloban) \\
\hline 13. kolovoza 1692. & $\begin{array}{l}\text { Omer Zenković, komandant Like i Krbave i } \\
\text { Fata, iz Novog }\end{array}$ & Jerolima $(A n k a)$ \\
\hline 31. kolovoza 1692. & Mustafa Atlić i Sibila iz Knina & Ivan (Omer) \\
\hline 10. listopada 1692. & Odobaša Pahučehavić i Emina iz Ključa & Jerolima (Kadifa) \\
\hline 30. studenoga 1692. & Mustafa Agrica serdar Velike Kladuše i Sulđa & Katarina (Sale) \\
\hline 13. veljače 1693 . & Šaban Mahurević i Rukija iz Skradina & Zvane (Omer) \\
\hline 13. veljače 1693 . & Šaban Mahurević i Rukija iz Skradina & Zvane (Bećir) \\
\hline 15. ožujka 1693. & $\begin{array}{l}\text { Šaban Kovačević i Ajna iz Like; Šaban } \\
\text { (suprug) Berić, harambaša iz Like }\end{array}$ & Anzola $(A s k a)$ \\
\hline 4. rujna 1693. & Horuz Nuvić i Kadira iz Gračaca & Magdalena (Kana) \\
\hline 12. travnja 1694 . & Osman Spahija i Afifa iz Like & Zvane (Mehmed) \\
\hline 30. travnja 1694 . & Mehmet Ramić i Kimeta iz Vrebca & Zvane (Ramo) \\
\hline 26. srpnja 1694. & Ređep Sofić i Merima iz Livna & Ivana $(A \operatorname{lm} a)$ \\
\hline
\end{tabular}




\begin{tabular}{|c|c|c|}
\hline Datum krštenja & $\begin{array}{l}\text { Podatci o imenu i prezimenu krštenikovih } \\
\text { roditelja }\end{array}$ & Krštenik/-ica/-ici \\
\hline 20. kolovoza 1694. & Mumin Odobašić i Zahija iz Bilaja & Katarina (Ajra) \\
\hline 4. siječnja 1695. & Hasan Vojvodić i Senada iz Majdana Starog & Jerolima (Jasmina) \\
\hline 4. siječnja 1695. & $\begin{array}{l}\text { Ibrahim Omerović i Selma iz Plive kraj } \\
\text { Glamoča }\end{array}$ & Marija (Kadira) \\
\hline 3. ožujka 1695. & $\begin{array}{l}\text { Alija Balilović iz Skradina; Osman (suprug) } \\
\text { Spahirović }\end{array}$ & Lujza (Ajra) \\
\hline 1. siječnja 1696. & Bećir Beščirević i Fatima iz Vrebca & Jelena (Latifa) \\
\hline 12. siječnja 1696. & $\begin{array}{l}\text { Alija Kaliković i Ajra, kći Huseina Zulića iz } \\
\text { Udbine }\end{array}$ & Augustina (Fata) \\
\hline 22. ožujka 1696. & Mumin Kisljenović i Kama iz Udbine & Antonija (Ava) \\
\hline 23. travnja 1696. & Idriz Rezo Pašić i Đula iz Bilaja & Marija (Fada) \\
\hline 15. listopada 1696. & Mumin Odobašić i Zahija iz Bilaja & (Mubo) \\
\hline 31. studenoga 1696. & Omer Glumac i Fersida iz Udbine & Katarina (Sadira) \\
\hline 13. lipnja 1697. & $\begin{array}{l}\text { Sutora Hasanović i Selma Puraković iz } \\
\text { Trebinja }\end{array}$ & Magdalena (Emina) \\
\hline 14. srpnja 1697. & $\begin{array}{l}\text { Sima Vulahinović i Zahija Šajinović iz } \\
\text { Trebinja }\end{array}$ & Uršula (Nudžejma) \\
\hline 14. srpnja 1697. & $\begin{array}{l}\text { Sima Vulahinović i Zahija Šajinović iz } \\
\text { Trebinja }\end{array}$ & Zvane (Ramo) \\
\hline 17. srpnja 1697. & Sutora Vlahinić i Selma & Mihael (Ibro) \\
\hline 17. srpnja 1697. & $\begin{array}{l}\text { Ibrahim Šajnović i Nudžejma Hasanović iz } \\
\text { Trebinja }\end{array}$ & Margareta (Zabija) \\
\hline 17. srpnja 1697. & Durak Vlahinić i Emina Hasanović iz Trebinja & Katarina (Selima) \\
\hline 27. listopada 1697. & $\begin{array}{l}\text { Ređep Bajrić i Zahira iz Velograda u } \\
\text { Mađarskoj }\end{array}$ & Cecilija (Harisa) \\
\hline 16. studenoga 1697. & Durak Trejić i Ivka iz Udbine & Zvane (Mustedan?) \\
\hline 4. siječnja 1698. & Mumin Odobašić i Zahira iz Bilaja & Antun (Husain) \\
\hline 27. siječnja 1698. & Omer Glavinić iz Udbine & Katarina (Đula) \\
\hline 29. ožujka 1698. & $\begin{array}{l}\text { Ibrahim Čenavordić i Artiđa Mustafić iz } \\
\text { Bihaća }\end{array}$ & Marija (Safija) \\
\hline 13. travnja 1698. & Zahin Harlijević i Mirsada iz Rame & Marija (Zahija) \\
\hline 30. studenoga 1698. & Rismo Krilavić i Mihra iz Knina & $($ Lata) \\
\hline 7. lipnja 1699. & Hasan Pančijević i Fatima iz Požege & Toma Ilija $(A l i)$ \\
\hline 28. kolovoza 1699. & Husko Merpunović i Kata iz Dabra & Vicka (Đula) \\
\hline 6. rujna 1699. & $\begin{array}{l}\text { Omer Adžić i Muba iz Udbine; Alija (suprug) } \\
\text { Čejković }\end{array}$ & Anamarija (Abira) \\
\hline 1. rujna 1700. & Ibrahim Spahija Glumac i Fatima iz Udbine & $\begin{array}{l}\text { Katarina Domenika } \\
(A j k a)\end{array}$ \\
\hline 5. rujna 1700. & Bećir Murečanin i Kadira iz Bilaja & Perina $(B i b a)$ \\
\hline 22. prosinca 1700 & $\begin{array}{l}\text { Hasan i Đula Svirčević iz Kamengrada ispod } \\
\text { Majdan Starog }\end{array}$ & Katarina $(A j \check{s} a)$ \\
\hline
\end{tabular}




\section{Zdenko DUNDOVIĆ}

\section{BAPTISED TURKS IN ZADAR IN THE $17^{\text {TH }}$ CENTURY ACCORDING TO THE REGISTERS OF THE CATHEDRAL PARISH OF ST. ANASTASIA}

\section{SUMMARY}

On the basis of entries of names of baptised Turks into the registers of the parish of St. Anastasia in Zadar for the $17^{\text {th }}$ century, the paper tackles the issue of baptising the population from the territory under Ottoman authority in the context of organised human trafficking in Zadar and its surroundings, conducted in the fold of Venetian Republic, in particular during turbulent time of the Kandyan War (1645-1669). In the geo-strategic sense, the Zadar area was at that time not only the watershed of three military-political powers: Venetian Republic, Ottoman Empire, and Habsburg Monarchy, but also the meeting point and the venue of constant migrations of the population of different confessions in three territories (Catholic, Orthodox and Islamic). War devastations and the tactics of the so-called scorched earth accelerated the migration processes on the one hand, and reinstated the venues of human trafficking in the territory of Dalmatian communes on the other. Venetian Republic passed many legal provisions regarding improved control of human trafficking and state interests. One of these provisions stipulated obligatory baptising of slaves; this was intended to serve as a guarantee of their freedom and gradual inclusion into the society. The paper analyses the complexity of this process; inconsistent behaviour of Venetian authorities with regard to the implementation of its own provisions for the sake of military interest; and the role of the Catholic Church and its officials in baptising the Turks. Furthermore, certain details on the social status of slave masters and the nature of their mutual relations were issued; this enabled presenting - to a certain extent - the attitude of the Zadar bourgeoisie towards slaves and servants in the $17^{\text {th }}$ century. In conclusion, the paper defines the routes of slave trafficking from Zadar in the direction of the Apennine Peninsula in confirmation of active human trafficking having taken place in the area between the western and the eastern Adriatic coasts in the $17^{\text {th }}$ century.

Keywords: baptising of the Turks; baptising; Zadar; $17^{\text {th }}$ century; slave trafficking. 
